\title{
Realising 'dialogic intentions' when working with a microblogging tool in secondary school classrooms
}

Paul Warwick ${ }^{1 \star}$, Vic Cook ${ }^{1}$, Maria Vrikki², Louis Major ${ }^{1}$ and Ingvill Rasmussen ${ }^{3}$

${ }^{1}$ Faculty of Education, University of Cambridge, 184 Hills Road, Cambridge, CB2 8PQ, UK; $+441223767600$

2 Department of Education, University of Cyprus, P.O.Box 20537, 1678 Nicosia, Cyprus; $+22892940 / 1 / 2$

${ }^{3}$ Department of Education, University of Oslo, PO Box 1092, Blindern, Sem Sælands vei 7 , 0317 Oslo, Norway; +47-22844475

* Corresponding author: Paul Warwick - ptw21@cam.ac.uk

Co-authors: Vic Cook - vac36@cam.ac.uk; Maria Vrikki - mvrikk01@ucy.ac.cy; Louis Major Icm54@cam.ac.uk; Ingvill Rasmussen - ingvill.rasmussen@iped.uio.no 


\begin{abstract}
In this paper we argue that joint teacher and student awareness of dialogic intentions (DIs) in lessons can focus and guide students' spoken dialogic interactions in the context of the use of digital technology. We focus on $\mathrm{DI}$ as a factor in promoting metacognitive awareness of productive dialogue amongst students, considering how teachers in 'dialogic classrooms' express Dls and how the use of a microblogging tool (Talkwall) can support, enhance or disrupt students' realisation of these intentions. Data consist of 17 lessons with Year 7 students (aged 11-12), taught by six teachers and covering three subject areas: English, science and geography. A systematic model is used for analysis of technology-focused student interactions, revealing how technology affordances and constraints are implicated in the realisation of DI. This paper is significant in examining how the ability to engage in dialogue can be focused through learning intentions, or set of intentions, within lessons. Further, it considers how specific technological affordances are central to the ways in which technology is implicated in the creation of a relational space for intra-action that might support teaching and learning.
\end{abstract}

\title{
Keywords
}

Dialogic intention; micro-blogging; metacognition; assessment for learning 


\section{Introduction}

"I think for me, the focus on design with DIs has been really useful, because you know, that went a little bit by the wayside in my practice, and actually doing it again I [...] realised actually I knew this was valuable." Ben (Teacher)

In this paper we argue that joint teacher and student awareness of dialogic intentions (DIs) in lessons can focus and guide students' spoken dialogic interactions in the context of the use of digital technology. The idea that teachers should have clear subject domain learning intentions (a term often used interchangeably with 'lesson objectives'), and that these should be shared with students, is becoming mainstream in many countries, including in England (House of Commons, 2008). Yet research suggests that teachers may remain insecure in their understanding of the principles underlying the use of learning intentions in the classroom, and that engagement with students about them is relatively rare (Crichton \& McDaid, 2015). Where teachers are attempting to employ strategies that increasingly empower students, such as engaging them in discussions about the purpose and direction of their learning, they are often doing so as part of the 'challenge of transforming from monologic teaching to a more dialogic teaching approach' (Baird, Hopfenbeck, Newton, Stobart \& Steen-Utheim, 2014: 49), a challenge that has been consistently underestimated (Baird et al., 2014).

This paper is significant in examining how teachers, who are already engaged in a dialogic development of their practice, emphasise the ability to engage in dialogue itself as a learning intention, or set of intentions, within lessons. It considers whether there is uptake of these intentions in students' semi-autonomous group activities; here, uptake refers to whether, and how, students apply contributions, support and guidance from teachers or peers to their classroom activity and learning over time (van de Pol, Mercer \& Volman, 2018). Finally, it focuses on how spoken dialogue, the focus of such intentions, might be supported or constrained by students' use 
of a microblogging tool; in other words, how technology might provide a 'site' for the development of dialogue skills. The research questions that frame this paper are therefore:

How do teachers express dialogic intentions in their teaching?

In students' semi-autonomous group activities, how is student uptake related to teachers' stated dialogic intentions?

In what ways is the use of a microblogging tool implicated in the uptake of teachers' intentions for spoken dialogue in group activity in classrooms?

The focus technology in this research was Talkwall ${ }^{[1]}$. Developed by the University of Oslo, Talkwall is a bespoke microblogging tool, the development of which has been deliberately aligned to a specific research-based understanding of dialogic pedagogy, exemplified through the programme 'Thinking Together' (Mercer, Wegerif \& Dawes, 1999). Talkwall was thus initially designed to engage students in collective classroom interaction by directly involving technology into the high-quality discussion that supports learning. Throughout the wider project that formed the background to this paper, this design was tested in naturalistic settings and design features were modified as the work progressed. Typically in this project, a teacher formulated a question or a challenge for the students. Students worked in groups to post messages to the shared 'feed'. These messages could be interactively arranged or filtered on a shared class 'wall', supporting the immediate visualisation of ideas.

The shared class 'wall' can be created in classrooms equipped, ideally, with a large screen or interactive whiteboard, though any 'main screen' could be used. Students, using mobile devices such as mobile phones or iPads, individually or in groups, can contribute to this and to their own 'walls' on their devices. Though this may suggest that only technologically advanced societies 
might benefit from such tools, it is worth noting that organisations such as EdTech Hub ${ }^{1}$ are committed to increasing global equity in education and are exploring the viability of small numbers of mobile devices being deployed in classrooms. Thus, browser-based software such as Talkwall may have a place in less socio-economically advantaged areas of the world, specifically because it is used on such devices. However, it would be disingenuous to say that we have worked with it anywhere other than in 'technologically rich' classrooms.

We should be clear at the outset that we understand that student learning is influenced by numerous factors (Figure 1) and that the influences on individual and collective development are both myriad, complex and interrelated. To take just one of these influences likely to have an effect on whether students might engage dialogically in group settings, the problem of how the students' interpret a task has clear relevance, particularly in relation to the development of subject-related knowledge or skills (e.g. Rasmussen, Krange \& Ludvigsen, 2003; Lantz-Andersson, Linderoth \& Säljö, 2009; Newman, Griffin \& Cole, 1989). Indeed, interpreting a task set by the teacher and interpreting teachers' intentions might not be separate processes, or at least they might be somehow intertwined.

\footnotetext{
${ }^{1}$ https://edtechhub.org/
} 


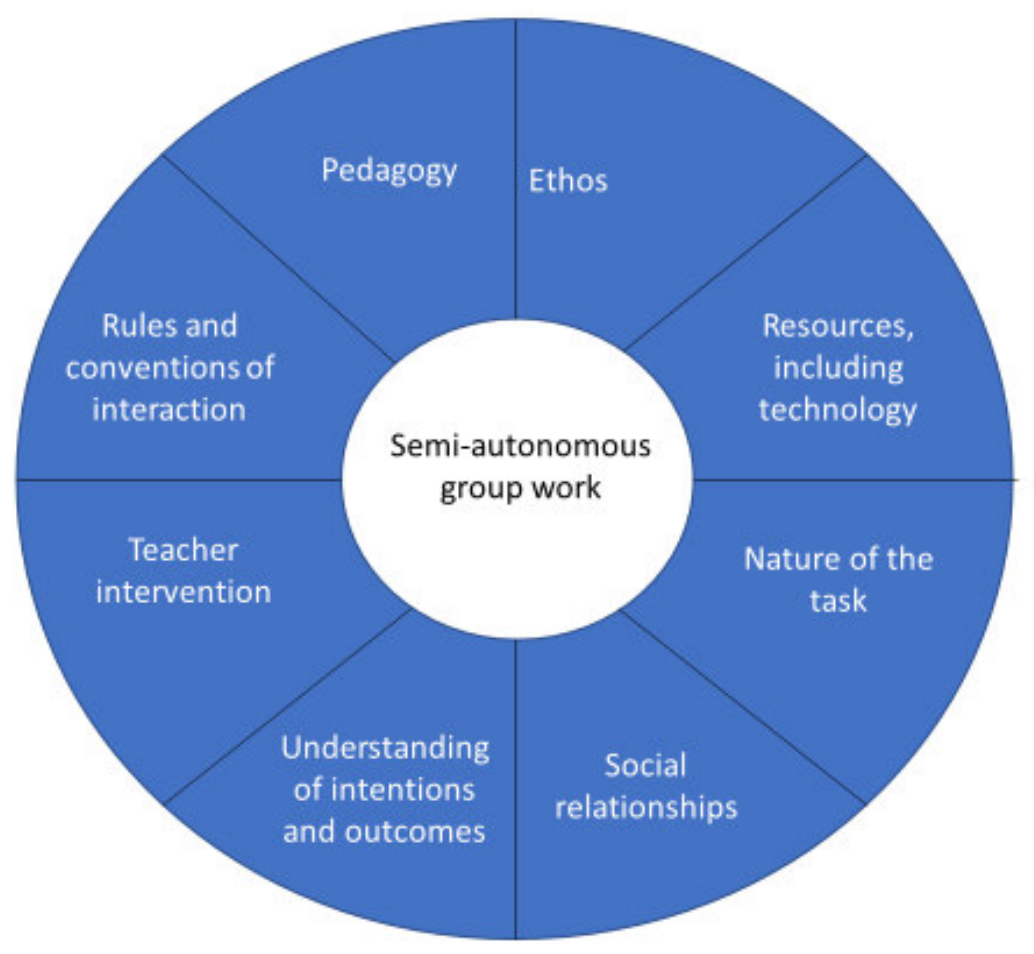

Figure 1: Some key classroom influences on learning in groups

Acknowledging such diverse and interconnected influences on student learning, this paper attempts to tease out, and throw light upon, the representation and uptake of DIs in the context of classroom technology use, where classroom activity is informed by a dialogic pedagogy and an associated classroom ethos. In so doing, we consider how digital technology may be implicated in realising DIs, stressing the idea that specific technological affordances are central to how technology is implicated in the creation of a relational space for intra-action that might support teaching and learning.

\section{Literature Review}




\subsection{Teaching and learning intentions within a dialogic pedagogy}

Marshall, Smart \& Alston (2016: 160) maintain that, whilst the teacher '... does not explicitly control students' actual behavior, they do control how they react to or proactively inhibit that behavior'. This 'inhibiting' includes teachers' intentional actions in focusing students' attention positively on learning objects, ideas and features of their own learning. Indeed, it has long been proposed that explicitly communicating instructional intentions can make teaching more effective (Marcos \& Tillema, 2006), improving student learning outcomes (Flick \& Dickinson, 1997). The idea that teaching and learning may be more effective if students understand both teacher intentions, and the ways in which outcomes related to them might be evidenced within a lesson, is a foundation concept within Assessment for Learning (AfL; Black \& Wiliam, 2009).

In this paper we support the case that others have made (Black, 2015) that the principles and practices of AfL mirror many of the characteristics of teaching and learning where a dialogic pedagogy is embedded. Classroom dialogue - with a focus on sharing and evaluating ideas, building ideas collectively, reasoning, providing justifications and elaborations, and using evidence to support arguments - is acknowledged as a particularly important tool for learning (Barnes, 1976; Alexander, 2008; Howe \& Abedin, 2013; Mercer \& Dawes, 2014; Schwarz \& Baker, 2016). Supporters of dialogic pedagogical practices maintain that classroom dialogue is 'central to the meaning making process and thus central to learning' (Mortimer \& Scott, 2003: 3), and there is strong and increasing evidence of the positive effects of a dialogic pedagogy on subject attainment outcomes (Baines, Blatchford \& Chowne, 2007; EEF, 2017; Mercer, Fernandez, Dawes, Wegerif \& Sams, 2003; Muhonen, Pakarinen, Poikkeus, Lerkkanen \& RaskuPuttonen, 2018; Rojas-Drummond, Littleton, Hernández \& Zúniga, 2010). But though classroom dialogue might be seen as central in developing teacher-student and student-student interaction 
for learning (Alexander, 2017a, 2017b), it seems that 'dialogic classrooms' are comparatively rare (Howe \& Abedin, 2013; Wells \& Arauz, 2006).

AfL focuses primarily on how feedback from lesson activities can enable teachers and students to adjust ongoing teaching and learning 'to improve students' achievement of intended instructional outcomes' (McManus, cited in Bennett 2011, p.6). Focusing on day-to-day classroom assessment, AfL has been conceptualised as consisting of five key strategies (Black \& Wiliam, 2009, p.8):

- Clarifying and sharing learning intentions and criteria for success;

- Engineering effective classroom discussions and other learning tasks that elicit evidence of student understanding;

- Providing feedback that moves learners forward;

- Activating students as instructional resources for one another; and,

- Activating students as the owners of their own learning.

Several ideas contained within these strategies pertain directly to the research reported here. Firstly, the clarifying and sharing of learning intentions and success criteria is conceived as being a reciprocal process engaged in by students and the teacher (James \& Pedder, 2006; Pedder, 2006). It might be considered as a vital first step in encouraging students to consider both their subject domain learning and, importantly, the metacognitive strategies that they employ to promote their learning in the lesson. Thus, whilst feedback is the stated driver of AfL, the 'feedforward' of shared intentions is also significant. Secondly, 'effective classroom discussions' can evidence understanding and are thus crucial to the formative learning characteristics of AfL. Lastly, students can support one another's learning by 'knowing and expressing different stuff'; in 
so doing they can gain further insights into their own learning and learning strategies and become activated as owners of their learning.

From this, there are apparent connections to the importance of dialogue in classroom settings (Clarke, Howley, Resnick \& Penstein Rosé, 2016; Howe and Abedin, 2013; Kuhn, 2016; Mercer, 2013); to children's active collaboration in group activities (Kutnick, Sebba, Blatchford, Galton \& Thorpe, 2005; Rojas-Drummond, Albarran \& Littleton, 2008); and to the idea that the involvement of teachers, acting as facilitators of learning, is central to developing children's understanding of what and how they are learning (Black, McCormick, James and Pedder, 2006). Teacher involvement here includes the articulation of learning intentions by the teacher, or their coconstruction by the teacher with the students. And since 'the degree to which students take up teachers' support is known to promote students' learning' (van de Pol, Mercer \& Volman, 2018, p.2), we are particularly interested in the relationship between intention and uptake. Interestingly, this has been a particular focus of research into language learning, revealing a positive association between a teacher clarifying intentions and subsequent learning (e.g. Tsang, 2004).

\subsubsection{Dialogic intentions}

Turning specifically to the idea of DI, where the focus is on the development of dialogue as a metacognitive tool for learning (Coltman, Warwick, Wilmott, Pino Pasternak \& Whitebread, 2013; Pressley \& Harris, 2006; Whitebread \& Coltman, 2010; Whitebread, Mercer, Howe \& Tolmie, 2013), here we focus specifically on how students come to understand that the ways in which they talk around learning tasks can be practised and can have a positive impact on task outcomes. The central idea is that students should be made aware, explicitly and regularly, of the need to employ 'core elements' of spoken dialogue - asking questions, presenting reasons, providing evidence where appropriate, giving justifications, elaborating on points made, summarising, and interpreting, responding to and building on the views of others. Such dialogic skills - which connect 
strongly with the development of critical thinking and collaborative problem solving (e.g. Howe \& Abedin, 2013; Kuhn, 2015, 2016; Mercer, 2013; Mercer, Dawes, Wegerif \& Sams, 2004) - are at the core of 'strategy knowledge', one of the three categories of metacognitive knowledge seen by Vandergrift, Goh, Mareschal \& Tafaghodtari (2006) as central to the process of cognitive selfappraisal. Thus, we define $\mathrm{DI}(\mathrm{s})$ as the statement(s) of learning intentions by the teacher that specifically relate to the development of the core elements of dialogic interaction, as listed above.

It seems unlikely that a simple statement by the teacher of intentions for learning - whether focused on domain-specific learning or on developing a metacognitive understanding of how to improve collective and individual learning - will, of itself, prove particularly effective for learning. Something more seems necessary, and this 'something more' is indicated by several writers considering the importance of classroom ethos. For example, those concerned with distinguishing between learning and performance approaches to learning make clear the importance of establishing a classroom ethos that supports a learning orientation in students (Slavin, 1987; Ames, 1992; Dweck, 2000; Midgley, Kaplan \& Middleton, 2001). Where developing a learning orientation amongst students is the overall objective - with its emphasis on understanding the importance of effort and involvement in the enterprise of learning (Dweck, 2012) - then classroom instructional demands, situational constraints and interactional expectations need to match these intentions. The desire to promote student self-regulation in learning, evident where there is a focus on developing a learning orientation, seems to mirror a similar aspiration amongst proponents of a dialogic pedagogy, with its emphasis on collectively sharing, evaluating and co-constructing ideas, and on using evidence to support arguments. The imperative of developing a mutually supportive classroom environment (Barron, 2003) therefore may be an important precursor to having DIs interpreted and acted upon by students. We return to this issue in the discussion.

Having briefly outlined ideas about the importance of teacher intentionality and the potential place of DIs in this intentional practice, we now consider how the idea of DI has potential to be realised 
through combining the use of digital technology with a dialogic pedagogy. In so doing we illuminate the importance of the classroom as a reciprocal site of interaction, in which the flow of dialogue between the digital and the spoken is 'central to meaning making'.

\subsection{Enacting DI through digital technology}

In recent years, much attention has been paid to the interaction between, and possible interdependency of, a dialogic pedagogy and digital technologies, extending the idea of 'interthinking' (Littleton \& Mercer, 2013). A growing body of evidence demonstrates how technology can enhance productive classroom dialogue in a number of ways (Major, Warwick, Rasmussen, Ludvigsen \& Cook, 2018). A focus has been on the mediating role of digital technology - for instance tablet computers, interactive whiteboards and computer-mediated communication tools (Haßler, Major, Warwick, Watson, Hennessy \& Nicholl, 2016) - in enabling collective knowledge building in classrooms (Hakkarainen, 2009; Rasmussen \& Ludvigsen, 2010; Scardamalia \& Bereiter, 1994). Proponents of Computer Supported Collaborative Learning (CSCL) (e.g. Sfard, 2008; Wegerif, 2006, 2007, 2013) also suggest that 'technologically mediated forms of discourse and interaction (can) provide new forms of discussion' (Stahl, Cress, Ludvigsen \& Law, 2014, p.118).

If we do indeed 'think with and through artefacts' (Säljö, 1995, p. 91; see also Arvaja, Häkkinen, \& Kankaanranta, 2008; Pifarré \& Kleine Staarman, 2011), then it seems clear that technology may have the potential not only to provide a basis for developing and enhancing classroom dialogue, but also to change the nature of dialogue. However, the influence of such 'materiality' has generally been omitted from dialogic educational theory. Hetherington, Hardman, Noakes \& Wegerif (2018), synthesising Bakhtin's (1986) work on dialogue and Barad's (2007) agential realism, propose a material-dialogic theoretical framework in which 'learning is an emergent and 
dynamic process performed through agentic intra-action with embodied teachers, learners and materials' (p.168). The concept of agency is important in our conception of the dialogic use of technology in classrooms, but requires explanation. According to Barad (2007, p.177), agency is understood in a relational sense - it is 'a matter of intra-action; an enactment, not something someone or something has'. Here the term 'intra-action' is used to highlight Barad's understanding of 'the mutually constitutive, entangled nature of matter and meaning' (Hetherington and Wegerif 2018, 29). As Hetherington et al. (2018) explain, this 'draws the material much more closely into the entangled relationships within a dialogic space ... the distinct voices in the dialogue do not pre-exist, but come into being through the intra-action within the relational space. (p.164); and this intra-action includes contributions from material 'voices', in our case the 'voice' of the technology. This relational space of intra-action is thus both material and discursive, and is encapsulated in their term 'material-dialogic space' (p.164).

Whilst Hetherington et al.'s work focuses specifically on how dialogue and materials intra-act to influence meaning-making within science classrooms, in this paper we build on previous work (Cook, Warwick, Vrikki, Major \& Wegerif, 2019), using a material-dialogic framework to understand how Talkwall may be implicated in the uptake of teacher's dialogic intentions. But whether the enhancement of spoken dialogue or the incorporation of technology as a 'voice' in dialogic interaction is the objective, it will be apparent from the arguments conducted so far that technology is unlikely to achieve this simply by being made available to students. Since the same technology can be used in the classroom in a range of different ways it seems that it is the pedagogy, not the technology per se, that is of central importance (Mercer, Hennessy \& Warwick, 2017). Thus, in a dialogic classroom it is our contention that the Dls of the teacher, determining the character of the tasks engaged in with technology, can '[open] up new kinds of opportunities for learners and teachers to publicly share, explain, justify, critique and re-formulate ideas ...using language and other symbolic representations' (Mercer et al., 2017, p.6). 
Turning to microblogging as the focus of this paper, extant research in a school context indicates that the key referential anchor is the contribution or post, usually in a relatively short response format that can be productive for starting conversations and increasing levels of participation and engagement (Gao, Luo, \& Zhang, 2012). Combining microblogs with interactive, shared screens (tablets and whiteboards) enables ideas to be visualised in order to facilitate students' joint knowledge construction, incorporating the 'voice' of the technology. In this way discussions may be developed as students are able to engage with alternative perspectives, and metacognition may be facilitated as students are encouraged to reflect on, and respond to, other people's 'posts' (Singleton, 2016). In one study, on microblogging in a history class, ideas were dynamically shared via a large screen, and students and teachers were able to dialogically elaborate on the content (Rasmussen \& Hagen, 2015). In this way, the microblogs and the shared screens represent an interface for students to visualise thinking, their own and that of others, and for the teacher to engage with students individually and collectively. In such work, it is the enacted affordances of the tool (Cook et al., 2019), with their use partly determined by the teacher's DIs, that may determine the dialogicality, or otherwise, of the activity.

In light of the ideas about the relational space of intra-action, and considering studies such as those just cited, the concept of affordance is significant in characterising and explaining people's work with technology (Oliver, 2005). First attributed to perceptual psychologist James Gibson (1977; 1979), affordance was developed to describe how individuals derive meaning from the world around them; it broadly considers what material objects in the world 'afford' individuals, in a relational sense (Osborne, 2014). Affordances are thus part of a relationship between an actor and artefacts, with these two parts of a whole system. Further, they may provide both opportunity and constraint (Magnusson 2010), '... for good or ill' (Gibson, 1979, p. 127). The concept has proven to be powerful, and it has been taken up as an explanatory device in a range of academic fields. As a result, important analyses of affordance used across academic disciplines (Hartson, 
2003; Turner, 2005; Bower, 2008; Vyas, Chisalita \& van der Veer, 2006; Hutchby, 2001) have led to Gibson's original notion of affordance evolving, with Kirschner (2002) and others (e.g. Oliver, 2005) cautioning that applying Gibson's original meaning of affordance to artefacts as complicated as educational technology can be problematic. Considering this in light of the educational use of digital technology, affordance is commonly understood in terms of possibilities for action, or 'action possibilities' (Osborne, 2014). However, as Osborne argued, viewing affordances in this way can result in a narrow fixation with "technologies as tools, 'things' to be prodded, pushed or pulled" (Osborne, 2014, p. 412). In a similar vein, we do not view affordances as passive characteristics of the technology that are waiting to be used; rather, we suggest that the technology plays an active role in material-dialogic intra-actions. Thus, we argue here, as we have elsewhere (Cook et al., 2019), that affordances are 'enacted' through material-dialogic intraaction. This perspective builds on Barad's (2007) concept of agency and is in line with Osborne's (2014) view of affordances in which he attributed agency to both the learner and the technology. We argue that this focus on enacted affordances emphasises the voice of the technology within the material-dialogic intra-action.

In what follows, we consider how teachers in 'dialogic classrooms' express metacognitive DIs as part of the overall learning intentions for their lessons. We further consider the ways in which they employ the microblogging tool Talkwall as a locus of dialogic activity in the classroom, using affordances to draw it into the relational space of intra-action.

\section{Methodology}

\subsection{Digitalised Dialogues across the Curriculum (DiDiAC)}

This paper draws on data from a four-year project (Digitalised Dialogues across the Curriculum (DiDiAC); this collaboration between the University of Oslo and the University of Cambridge aims 
to throw light on how students learn with technology, across three knowledge domains: language, social sciences and natural sciences. Data were collected from five secondary schools in Norway and two secondary schools in England, with approximately 400 students involved. Teachers involved in the research reported here identified themselves as broadly dialogic in their approach to teaching, and willing to be involved in development sessions that explored what this meant for their classroom practices. Following their self-nomination, each school selected the teachers who took part in the research. It was essential that a shared understanding of dialogic classroom strategies was developed amongst the research teachers, as the design of Talkwall, the microblogging tool used in the research, was predicated on its use within a dialogic frame of reference (Rasmussen \& Hagen, 2015). Thus, it was anticipated through the design process that Talkwall will be used in a way that encourages spoken dialogue between the teacher and students, and between students themselves.

Each class (Year 7 - students aged 11-12) engaged in a sequence of three research lessons, in which the microblogging tool Talkwall was employed in the learning. As discussed above, the teachers were actively working to understand and develop dialogic practices in their own interactions with students. For all of them, this included the initiation of a short programme of work enabling the students to develop, and practice using, dialogic ground rules for talk; these were created to act as frameworks for dialogue between the teacher and their students, and between the students themselves when working in groups (Mercer, 1996: Mercer, Wegerif \& Dawes, 1999; Mercer and Dawes, 2008). These students were thus being progressively schooled in the application of ground rules for talk, through teacher modelling and explanation, and through lessons in which they were expected to apply dialogic approaches to group interaction when working together.

\subsection{Data}




\subsubsection{Organising and categorising the data corpus}

In both Norway and England, the research lessons were video-recorded and transcribed. Two cameras were used in the recordings of each lesson, one focusing on the shared Talkwall screen and the other panning from the whole class context to a specific group of students, when the class was asked to work in groups. 'Focus' groups in each class were selected in consultation with the class teachers, who were asked to provide details of two groups of three students - one focus group and a 'back-up group' in case of student absence. No further specifications were made beyond a requirement that the groups should be of mixed ability. All appropriate permissions for video recording and data dissemination, for both teachers and students, were followed (BERA, 2018; NSD - see acknowledgements).

For the project as a whole, the English and Norwegian data were comprehensively reviewed, categorised and organised within Microsoft Excel to enable later systematic data analysis in answer to specific research questions. This characterisation and presentation of the total data set involved a progressively more fine-grained categorisation, through a consideration of the Communicative Situation, Communicative Events and Communicative Acts (Hennessy, RojasDrummond, Higham, Márquez, Maine et al., 2016). Here, the 'Communicative Situation' provided a 'thick description' (Geertz, 2008) of the classroom and school setting, building on field notes. The 'Communicative Event' level provided a minute-by-minute analysis identifying whole class or group activity; interactive or non-interactive communicative approaches (Mortimer \& Scott, 2003); and student- or teacher-led uses of Talkwall.

Finally, for 'Communicative Acts' a turn-by-turn analysis of spoken dialogue was undertaken. This level of analysis drew on the large body of research on educational dialogue, and particularly its methodological aspects. Adopting a sociocultural theoretical perspective (Vygotsky, 1962), this field (and our work) views dialogue as the mechanism of collective thinking (Hennessy, Rojas- 
Drummond et al., 2016). Dialogue moves that were considered to align with the focus of this project as a whole - with its primary focus on developing critical thinking (Kuhn, 1991) - were included in our system of analysis. More specifically, six coding categories were selected from the 'Cambridge Dialogue Analysis Scheme' (CDAS: Vrikki, Wheatley, Howe, Hennessy \& Mercer, 2018). As shown in Appendix 1, these include the invitation and statement version of elaboration (i.e. building on ideas), the invitation and statement version of reasoning (i.e. providing explanations, justifications), querying (i.e. expressing disagreement) and coordination (i.e. synthesis of ideas). As explained by Vrikki et al. (2018), the two invitation codes captured authentic questions that would provide thoughtful responses (Nystrand et al., 1997); the elaboration, reasoning, and querying codes reflected core features of exploratory talk (e.g. Littleton and Mercer, 2013); and the coordination code stressed the importance of establishing connections. In other words, these codes reflected the dialogue moves expected to be seen in discussions of collective knowledge building associated with critical thinking.

Binary coding was used to determine the presence or absence of each code per turn. Each code could be used once per turn, even if it appeared more than once in a single turn. The six coding categories were tested for reliability, with eight Talkwall-related episodes ( $10 \%$ of the total number of episodes in the English data) being double-coded. Appendix 1 presents the codes, their definitions and their reported level of agreement.

\subsubsection{Data analysis}

This progressively fine-grained organisation and categorisation of the overall data meant that, in addressing the research questions central to this paper (Introduction), we were able to identify relevant data from the corpus. The data examined for this paper comes from the English database, which comprises 17 video recordings of lessons, taught by six teachers working with Year 7 (students aged 11-12) in two secondary schools; lesson planning for these lessons; and 
transcripts that include spoken dialogue and digital logs of participants' Talkwall activity. There were two main stages of analysis.

Firstly, we analysed the lessons as a whole. In terms of DI, all lesson data was reviewed for the ways in which this was stated verbally by the teachers during the observed lessons. This process was carried out by members of the research team, with subsequent review meetings enabling the broad categorisation of dialogic learning intentions as either specific or generic (Table 1).

\begin{tabular}{|c|c|}
\hline Specific Dls & $\begin{array}{l}\text { 1. To deepen thinking through challenging each other } \\
\text { 2. To work on trying to reach agreement, backing up } \\
\text { ideas with reasons } \\
\text { 3. To reach agreement by explaining and questioning } \\
\text { each other ( } 2 \text { instances) } \\
\text { 4. To reason and come to agreement ( } 3 \text { instances) } \\
\text { 5. To question and ask others to explain or elaborate } \\
\text { 6. To share, justify and build on ideas and opinions, } \\
\text { include everybody and reach agreement } \\
\text { 7. To back up ideas with reasons, and to be prepared to } \\
\text { challenge other people's ideas if they don't provide a } \\
\text { reason } \\
\text { 8. To share (geographical) ideas and to ask each other } \\
\text { to back up ideas with reasons } \\
\text { 9. To ask questions } \\
\text { 10. To share ideas or information } \\
\text { 11. To share, build on and challenge ideas to improve } \\
\text { them } \\
\text { 12. To ask each other 'why do you think that?' } \\
\text { 13. To ask each other 'why do you think that?' so ideas } \\
\text { are backed up with reasons } \\
\text { 14. To ask each other 'why do you think that?' } \\
\text { 15. To strive to reach an agreement (even though this will } \\
\text { not always be the case) }\end{array}$ \\
\hline Generic & $\begin{array}{l}\text { 1. To listen carefully and communicate clearly } \\
\text { 2. To work together as a group to discuss ideas } \\
\text { 3. To involve everybody } \\
\text { 4. To talk and listen, before arriving at a conclusion (2 } \\
\text { instances) } \\
\text { 5. To work together as a learning community, using } \\
\text { XXXX } \\
\text { 6. To cooperate with classmates }\end{array}$ \\
\hline
\end{tabular}

Table 1: Characterising Dls across all research lessons 
Here, the 18 instances of the use of 'specific Dls' are more strategic in character (Vandergrift et al., 2006), reflecting a concern to target particular aspects of dialogue. The 6 instances of 'generic DIs' have more the character of broader exhortation to behave in a particular manner, or to adhere to a learning ethos related to open, positive communication in the classroom. In only one lesson was a generic intention stated without there also being a specific DI. This was 'To listen carefully and communicate clearly', and though it might be argued that the focus on listening specifies the use of a particular skill, the DI was expressed in broad enough terms to be designated as generic. In all other lessons the teachers employed a mixture of specific Dls and more generic intentions.

Having analysed whole lessons for evidence of planned and stated DIs, we then looked for uptake of these Dls in student group activity. To identify group episodes relevant to the third research question, we used a combination of two identified Communicative Events (Talkwall Usage and Group Activity) to initially pinpoint potentially relevant episodes for analysis (51 in total); it should be noted that these were also group episodes where the teacher had little or no direct involvement with students. Groupwork episodes that were rich in spoken dialogue moves, identified by the dialogue coding, were then shortlisted for further investigation; it was these that we hypothesised as having the potential to reveal an association between stated Dls and student uptake of these intentions.

In order to investigate the role of Talkwall in supporting, enhancing or disrupting the realisation of the DI, however, it was also important to characterise the episodes shortlisted thus far in terms of the nature of Talkwall use. Here, each episode was classified as either 'product' or 'process'. A product episode was one in which Talkwall was being used more broadly as a presentational tool, generally meaning that the group dialogue had occurred prior to its use; in this sense Talkwall was being used as a 'passive tool' (Beauchamp, 2011). Conversely, a process episode involved the use of Talkwall as an 'active tool' that provided 'a medium to interact through' (Beauchamp, 2011, p.187); such episodes were particularly relevant to us in terms of our expressed interest in 
the discursive relational space of intra-action between students and technology (see Section 2.2). In selecting episodes of interest for this paper we therefore focused on the 29 process-based episodes (of the 51 initially identified) where the frequencies of dialogue moves suggests that there was clear evidence of dialogic interactions between group members (Appendix 2).

Process episodes of group activity were further analysed in terms of Talkwall use, through a review of the affordances for dialogue enacted in each episode. In line with our interest in the use of Talkwall as an active 'voice' in interactions, we conceptualise 'affordances' as enacted or realised through the use of TW, rather than being passive 'characteristics' of the technology that are adopted. As Cook et al., (2019) and Major \& Warwick (2019) make clear in work that considers the idea of enacted affordances for dialogue in some detail, 'we advocate a view of affordance as acknowledging 'action possibilities', but additionally highlighting the value of recognising the closely related idea of 'enactment'; that is, how affordances are specifically implicated in promoting dialogic interaction for learning' (Major \& Warwick, 2019, p.400). In being very specific about a focus on affordances for dialogue, and seeing technology as having a relational 'voice' in interactions, we align ourselves with Osborne's (2014) recent analysis of affordance as a design tool for aligning pedagogy and technology. It is useful here to draw on the work of Cook et al. (2019) to briefly outline how the list of enacted affordances used in our work was established. Thus:

'The enacted affordances of Talkwall were categorised through inductive and deductive processes, informed initially by the literature, including Bower (2008) work on the spatial affordances of technology and research on provisionality (Warwick, Mercer, Kershner, \& Klein Staarman, 2010; Beauchamp \& Kennewell, 2008). A second round of coding was then undertaken by two of the reviewers and the themes were subsequently revised and refined... It was not possible to conduct systematic double-coding and test for reliability because there is no specific unit of analysis for affordances - the effect of an affordance 
can be felt long after the moment of its enactment so it is not possible to agree where an affordance begins and ends.' outlines these enacted affordances, indicating broadly the nature of the enactment with this specific tool; this is not meant to indicate that they would not be apparent when using other tools, but it does indicate how the affordances were specifically realised in this case. (Cook et al., 2019, p.223)

This process of analysing enacted affordances led to the detailing of the following enacted Talkwall affordances - browsing, selection, positioning, support/challenge, provisionality, assistive memory and control (Appendix 3). These were used to further refine episodes of interest for this study.

As a result of this detailed review (Figure 2), seven episodes were selected for more detailed analysis of interaction. They shared the following features: i). a range of spoken dialogue interactions; ii) process use of Talkwall as an active agent in the dialogue; iii). use of various Talkwall affordances. We acknowledge that other selection criteria might have been used, but these three features link strongly back to our research questions. 


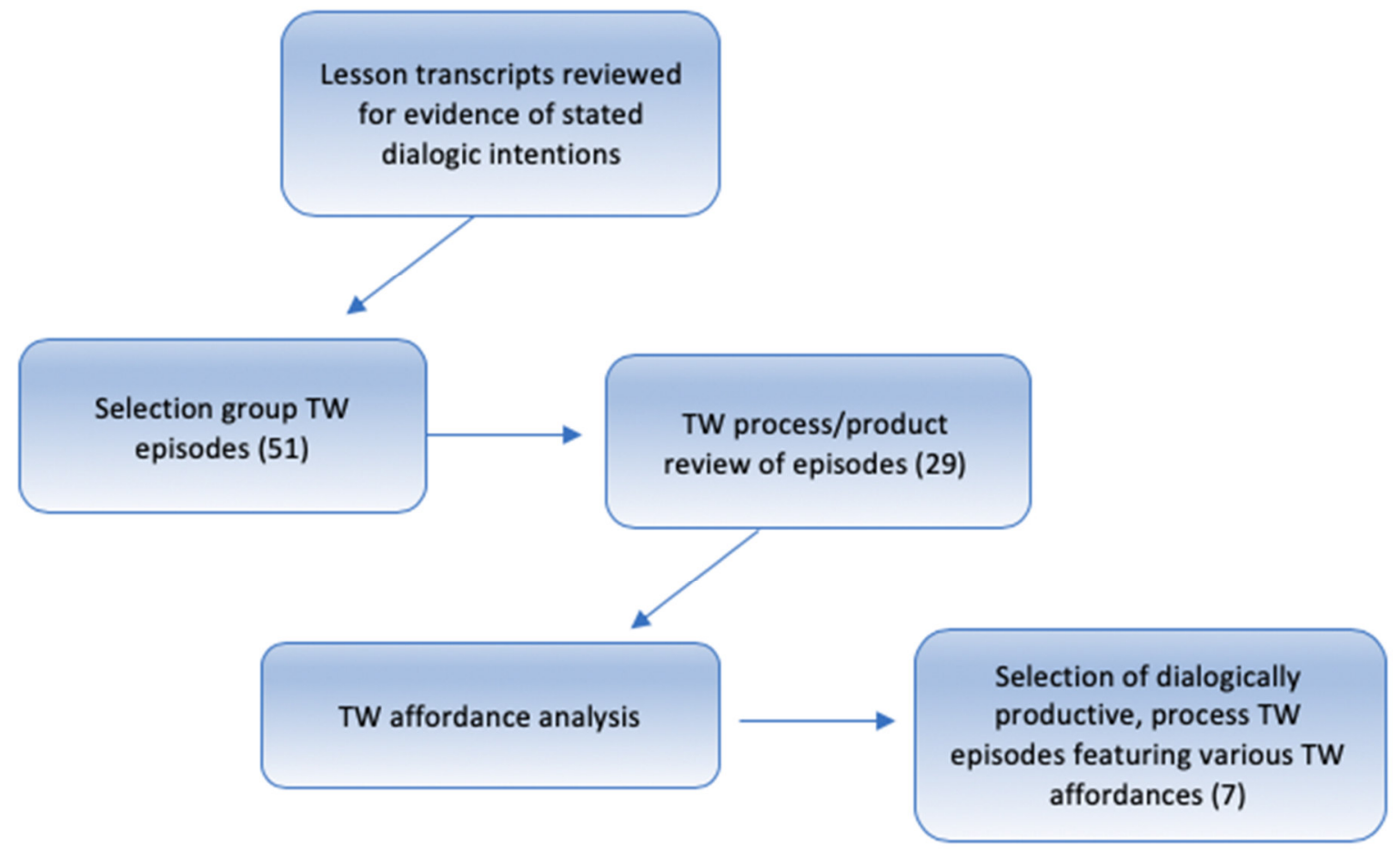

Figure 2: Arriving at the episodes for detailed analysis of interaction

Jordan \& Henderson (1995) present a clear rationale and framing set of assumptions for employing a micro-analysis of interactions in the context of an examination of group talk and interactions with technology. They further articulate the imperative of repeated viewing of video extracts to enable the fine-grained analysis required to address research questions that focus on the nature of such interactions. At this stage then, the research team again employed the technique of repeated viewing, framed around the coding of dialogue and Talkwall affordances that support it, followed by discussions of episodes. This process provided a micro-analysis of the ways in which the teacher's stated Dls informed the interactions around Talkwall, and how Talkwall was implicated in these interactions. The micro-analysis focused on student-student interactions and the ways in which it was implicated in these interactions to influence the 
realisation of the DIs. In the findings below, one of these episodes (Section 4.2) provides an illustration of the process of detailed analysis.

\section{Findings}

\subsection{Dls, spoken dialogue and Talkwall affordances}

The 29 group process episodes and the associated Dls for the lessons are summarised in a table in Appendix 2. From this table it is apparent that there is not a simple association between stated Dls and dialogue moves undertaken by students. For example, elaboration (EL) was high in a range of episodes where students were variously asked to share ideas, build on ideas, reason or challenge and question. Reasoning (RE) was high in episodes where students were asked to challenge and/or question and to reason. Querying (QU) was also associated with being asked to reason and to challenge, although this did not always hold true (episodes 5 and 7 ). There are no recorded instances of coordination (CO), which involves synthesising or summarising two or more ideas, in any of the 29 episodes. This is particularly interesting for those lessons where either the specific or general DI was for students to try to reach agreement, as some level of coordination might perhaps be seen as fundamental to this process. This is consistent with other research that found coordination rarely observed in classroom dialogue (Vrikki et al., 2018); however, for us this raised a question about the specification of dialogue codes, addressed in the discussion.

Lessons 15 and 17 are interesting because they share the same DI ('to reach agreement by explaining and questioning each other') but with very different results. In lesson 15 there are very few dialogue moves, whereas lesson 17 appears to be much more dialogically productive, particularly in terms of elaboration and reasoning. This may well reflect the fact that lesson 15 was the first research lesson for this teacher, whereas lesson 17 was the third. The embedding 
of a dialogic ethos may therefore have led to the same DI being interpreted by the students much more effectively for learning in the third lesson.

Overall, where DIs are clearly stated, uptake is generally evident in associated group work, although this seems to be in part influenced by the underlying dialogic ethos of the classroom. Again, we return to this point in the discussion.

Appendix 4 presents the frequencies of dialogue moves in the seven focus episodes (see Section 3.2.2), alongside the range of Talkwall affordances that occurred in each of them and in light of the teacher's stated DI(s) for the lesson. The table indicates whether an affordance was present in the episode, not how many times it was observed. It was impossible to determine a defined unit of analysis for this, as enacted affordances may facilitate a momentary interaction or sustained engagement; in Section 4.2 it will be clear how we have tried to represent this in transcripts. This summary of seven focus episodes thus helps us to start to characterise the interaction of Talkwall affordances with spoken dialogue as it relates to Dls. As with a consideration of the relationship between dialogue moves and DIs in the 29 episodes above, the situation is complex. There is, unsurprisingly, no one-to-one relationship between the enacted affordances of the tool and specific dialogue moves, and the relationship between these and Dls is similarly not straightforward. Nevertheless, some conclusions may be drawn. The specific DI of 'sharing ideas' and the general DI of 'co-operating with classmates' appears to be strongly linked to the use of browsing. As students browse contributions posted to the shared feed, they are able to elaborate upon, reason with and query other groups' ideas, thereby widening the learning community. In contrast, the specific Dls of 'trying to reach agreement' and 'inviting reasoning/giving reasons' are linked with a wide range of affordances. This may depend partly on the specific nature of the task that has been set. For example, where students are asked to agree on the choice and categorisation of other group's ideas, selection and positioning will be enacted (Appendix 4, episode 2). Provisionality may also be enacted when inviting reasoning and backing up ideas with 
reasons, as ideas develop and thus the content of a contribution or it's categorisation may change (Appendix 4, episodes 14, 15, 16 and 19). It appears that revisiting previous ideas via the enacted affordance of assistive memory may also be implicated in reasoning (Appendix 4, episodes 2, 14, 16 and 19) and trying to reach agreement. However, in order to tease out the specific ways in which Talkwall enabled, and constrained, student interactions to influence the realisation of DI we need to move to a more fine-grained analysis.

To provide an exemplification of the ways in which Talkwall was implicated in students' uptake of spoken dialogue, and how this was associated with the teacher's DI, we present below a microanalysis of a selection from one episode (Appendix 4, episode 2). This process episode was chosen as representative of the approach taken to the analysis of the seven episodes outlined in Appendix 4 ; for presentation purposes in this paper, it contains a range of affordances and dialogic moves, and therefore allows exemplification of themes across the data.

\subsection{Analysis of interaction}

The presented science lesson with Year 7 students was 100 minutes long and featured phases of whole class teaching, group activity with and without Talkwall, research work by the students, and watching of video material selected by the teacher, who was in his tenth year of teaching. To quote the teacher's lesson plan, this was a 'synoptic lesson to bring together all of the [students'] learning studied during the World's Collide study period'. It focused, in part and in the episode presented here, on the students' perspectives on who might be given a place on a spaceship in a scenario where Earth was threatened by a giant asteroid. As we do in the introduction, we must acknowledge the impact that task interpretation itself has on students' responses to a task. Rajala, \& Sannino (2015), for example, discuss how students 'deviate' from assigned tasks, partly because they bring their own contexts to it. Here, we acknowledge the influence of student's contexts and emotional responses to the task on task interpretation. In the example presented 
here, however, we hope that it is clear that the task is deliberately open-ended, providing a problem likely to engage the students in dialogue and actually allowing them the freedom to incorporate their own ideas. Again, it is helpful here to reiterate that our focus is not on subject learning but on the children's interpretations of metacognitive strategies for engaging with ideas, the extent to which their dialogue seems to be influenced by the specific focus of the teacher's DIs, and the ways in which technology is implicated in this engagement.

In this work, then, the teacher's wider meta-cognitive remit is evidenced in his lesson planning, which states that 'learners will be focusing on learning through the following lenses:

- $\quad$ Curiosity - What is going to happen to us?

- Collaborative - Learners work together to come to decisions.

- Communicate - Learners share ideas, listen and respond to each other.

- The talk [intention] for this session is to work on trying to reach agreement. They will need to justify their reasons and make decisions.'

With a whole-school focus on developing curiosity, collaboration and communication, the expression of DIs in planning might be seen as partly stated in relation to these first three foci. However, specific Dls are stated in addition, and it is these that the teacher focuses on when talking to the students in the lesson. Thus, 'trying to reach agreement, backing up ideas with reasons' is the focus when the teacher expresses his Dls to the students; he frames the discussion of these in relation to the ground rules for talk that the class have previously established (Mercer, Wegerif \& Dawes, 1999).

As part of their first Talkwall task, the students were asked to decide which five categories of people would be allowed to leave Earth on a rocket to establish the human race on another planet. After discussion, these were submitted by the student groups as separate contributions to a 'wall' 
on Talkwall entitled 'How can we decide who gets to stay?'. This product task on Talkwall established the base of 'data' from which subsequent process tasks could spring. In the second task, extracts from which are presented below, the students have been asked to select what they think are the five most important contributions from the entire Talkwall feed (so, from groups across the whole class) and place these in any order on the top half of their horizontally divided wall. They then had to select the five least important contributions and place these in any order on the bottom half of their wall. As indicated in the teacher's planning, the specific DI for this lesson was twofold: i). to work on trying to reach agreement (linked to decision-making); and ii). to back up ideas with reasons. The first of these was stated at the start of the lesson, when the teacher discussed the importance of compromising when trying to reach agreement. At the start of this Talkwall task, the teacher reiterated this first DI, later refining it by emphasising the need for reasoning in decision making.

Below we present an initial extract of discussion within the group, with the coded dialogue moves and Talkwall affordances recorded. As noted previously, the table indicates whether an affordance was present in the episode, not how many times it was observed.

\begin{tabular}{|l|l|l|l|}
\hline Turns & Edited transcript & $\begin{array}{l}\text { Affordances } \\
\text { evident }\end{array}$ & $\begin{array}{l}\text { Dialogue } \\
\text { moves }\end{array}$ \\
\hline 1 & $\begin{array}{l}\text { Zac: Right, Francis, come here. So I've already put royal } \\
\text { family at the bottom, because I decided that they're born } \\
\text { rulers, so they're not necessarily good rulers. We definitely } \\
\text { need these (three) of ours, I'm just gonna ... Do you think } \\
\text { we definitely? }\end{array}$ & $\begin{array}{l}\text { SEL } \\
\text { POS } \\
\text { AM }\end{array}$ & RE \\
\hline 2 & $\begin{array}{l}\text { Travis: Healthy men, healthy children } \\
\text { Francis: And healthy wives. }\end{array}$ & - & \\
\hline 3 & \multicolumn{2}{|l|}{} & - \\
\hline
\end{tabular}




\begin{tabular}{|c|c|c|c|}
\hline 4 & $\begin{array}{l}\text { Zac: We don't need orphans, because the orphans could } \\
\text { be children; they're not necessarily orphans or children. } \\
\text { They're not meant the same, orphans or children ... }\end{array}$ & & RE, QU \\
\hline 5 & Travis: Yeah, I don't think orphans are necessary ... & BROW & - \\
\hline 6 & Zac: ... we don't necessarily need to put orphans, yeah. & & - \\
\hline 7 & Francis: I'd say doctors. & & EL \\
\hline 8 & Zac: Yes doctors would be in here. & $\begin{array}{l}\text { BROW } \\
\text { SEL } \\
\text { POS }\end{array}$ & - \\
\hline 9 & $\begin{array}{l}\text { Francis: We're going to need like } 50 \text { doctors on the } \\
\text { (inaudible). }\end{array}$ & & EL \\
\hline 10 & Travis: 50 , that's not a lot. & & QU \\
\hline 11 & $\begin{array}{l}\text { Zac: I know. Do you think we need international like pilots? } \\
\text { I think the rockets should know where they're going. }\end{array}$ & & ELI, RE \\
\hline 12 & Francis: Shouldn't we have like spacemen? & SUPP & ELI \\
\hline 13 & $\begin{array}{l}\text { Zac: Yeah, but I think, I should say I would think they're all } \\
\text { going to be programmed to go, because they've got } \\
\text { autopilots these days. }\end{array}$ & & RE, QU \\
\hline 14 & Francis: Fair enough. & & - \\
\hline 15 & $\begin{array}{l}\text { Travis: But, what, the thing is, how would - if we were to } \\
\text { repopulate, how would we? We couldn't build any more } \\
\text { ships could we? We couldn't build any more rockets. }\end{array}$ & & ELI, QU \\
\hline 16 & Zac: No, we're going to a different Earth like planet. & & QU \\
\hline
\end{tabular}

Table 2: Episode of interaction 
This part-episode represents the relationship of dialogue moves and affordances presented in Appendix 4 (episode 2). Here, the 'twin' Dls of working on trying to reach agreement and backing up ideas with reasons might perhaps suggest that the students need to engage in dialogue moves that reflect reasoning, querying, elaboration and inviting elaboration from others. Such moves are evident; however, as we have noted above, one might also expect coordination to be a feature or working on trying to reach agreement, and this is not seen. The affordances of browsing, selection, positioning, assistive memory and support are all used in engaging Talkwall as a 'voice' in the discussion to draw attention to ideas and employ them within the spoken dialogue. At the beginning of this extract (turn 1), Zac is scrolling through the contribution feed, on which all of the posted ideas from any group in the class can be accessed by all class members, before calling Francis over to join the group. Zac explains why he has already independently selected and positioned another group's contribution ('Royal Family') in the bottom half of the screen, disrupting the DI of trying to reach agreement. By beginning to pin other contributions to Talkwall, Zac 'suggests' that the group should select three of their own contributions ('healthy women', 'healthy men' and 'healthy children'), prompting the other group members for their thoughts. The group appears to agree to pinning their own contributions (turns $2 \& 3$ ). It is possible that they readily agree to using these contributions without any further exploration because the thinking behind them has already been done in the previous task. Here the enactment of assistive memory, as students intra-act with their own ideas, appears to facilitate a realisation of the DI of reaching agreement.

On turn 4, Zac discusses an idea about orphans; this is part of the contribution feed but did not come from their own group. Exposure to other groups' ideas on the Talkwall feed therefore widens the community of learners and enables students to reason with another group's idea. Providing a justification for not including this idea, which is followed by agreement from Travis (turn 5), links to the lesson's 'twin' Dls. Here, cumulative talk (Mercer, 1995) is used to realise the DI as the 
students check with each other and make sure that all members of the group agree not to include orphans in their thinking, leaving the idea on the contribution feed before moving on to the next idea. From this extract we can see how the Talkwall contributions have become an extension of the group's verbal reasoning processes as the dialogue and contribution 'intra-act' to influence the uptake of the teachers' DI, enabling the learners to think together with the material. As the students intra-act with Talkwall contributions within this relational space, though the enacted affordances of the tool, the voice of the technology is brought to the fore; furthermore, the materialdialogic space is both widened and deepened, as new ideas are introduced, reasoned with and queried.

Francis, who is standing behind Zac and Travis who are seated at a desk, then reaches over Zac's shoulder to browse through the contribution feed. Throughout this extract, the students' continual pointing and manipulation of the Talkwall feed highlights the corporeal nature of material-dialogic space, or its 'concrete' aspect (Wegerif \& Major, 2018). Francis suggests an idea from another group's contribution ('Doctors to help and cure any injuries or illneses', sic) that he has read on the feed (turn 7). The affordance of browsing, enacted through Francis' intra-action with another group's idea again widens the material-dialogic space, leading to assent from the group members. Zac agrees with Francis's suggestion and selects and positions the contribution onto the top half of the wall, again demonstrating how the group's use of cumulative talk links to the DI. Francis elaborates on the idea, suggesting a number of doctors that they will need (turn 9). Here, the material-dialogic space is deepened as Francis intra-acts with another group's contribution. This is a reflection of the dialogic ethos of the classroom, in which students are encouraged to discuss other people's ideas; and it demonstrates how a microblogging tool can be used, in conjunction with a dialogic pedagogy, to promote spoken dialogic activity. We shall return to this link between the realisation of Dls and the ethos of the classroom in the discussion. 
Travis queries the number of doctors suggested by Francis (turn 10) and Zac agrees with Travis but takes the idea no further (turn 11). By stopping any further exploration of this idea before any agreement can be reached, Zac is temporarily disrupting the realisation of the DI. Instead, Zac points briefly to a contribution on the feed and then questions the relevance of 'international like pilots' (seemingly referring to another contribution on the feed that references 'NASA rocket pilots'). Francis then briefly points to the feed and invites further elaboration on the idea under discussion, thereby supporting the group's decision making (turn 12). Zac queries Francis's suggestion, providing a clear reason for his earlier assertion that a pilot may not be necessary, and Francis agrees (turns 13-14). Throughout this extract, the affordances of browsing, selection, positioning and support, enacted through students' intra-action with Talkwall, can be seen as facilitating a form of dialogue between the students and Talkwall as the contributions push themselves into the students' learning.

Travis then invites elaboration on an earlier idea about taking men and women 'to repopulate' (turn 15). Travis seems to be drawing the group back to a central focus of the overall task. In the turns that follow (not presented here), Travis wonders about an alternative scenario that would help a larger part of the population to travel; this involves making a stop to Mars. Zac disagrees by pointing out that Mars is uninhabitable, which then prompts Travis to pick up a second iPad and explore the idea further. At that point, the teacher comes over and has a discussion with the group about the piloting of the spaceship.

In this brief part-episode, we get an insight into the naive reasoning and positioning of perspectives that might be expected from 12-year olds. However, we also see that they are perfectly willing to engage in dialogue related to the work undertaken in their study period; that much of what they discuss links with the $\mathrm{DI}(\mathrm{s})$ stated by the teacher; and that Talkwall affordances are enacted in a way that foregrounds its 'voice' in the dialogue. 
Further discussion in this episode (not presented here) sees the group considering moral issues, stimulating ideas about the worth of both 'bad people' and pets in an estimation of who should stay and who should leave a doomed Earth. Throughout, spoken dialogue and related Talkwall use, strongly linked to the lesson $\mathrm{DI}(\mathrm{s})$, is evidenced. What we focus on includes the teacher's intervention at the end of the episode; we then consider the teacher's next steps at the conclusion of the group work.

In returning to a whole class discussion after this episode, the teacher led an analysis of group choices, using Talkwall on a large interactive screen to move between group walls. This activity was framed by the teacher, who referred to his circulation between groups in the lesson by stating: "not everyone was lucky enough to hear all the discussions I heard, so this helps us to share them". He focused particularly on the reasons why some groups had chosen to replace some of their own responses to the initial activity with those of others in the subsequent group task. Here the teacher engaged in a genuine dialogue with the students by, for example: asking one group why they had chosen to include women and babies to go, with the students in that group emphasising longevity as important on the coming journey (Figure 3); asking a second group about the age of their selected leavers, again prompting justification and reasoning; and showing how, in another group, members had been persuaded to change their minds and come to agreement because of reasoning by one member. Thus, the teacher used the discussion around group Talkwall posts to explicitly link teacher support with student uptake (van de Pol et al., 2018), coordinating a discussion emphasising the ways in which he has perceived the groups have responded to the Dls for the lesson. Here we see coordination in the sense expressed by the dialogue coding scheme (Appendix 5). Dialogue coordination emerges from the intra-action of teacher and students with Talkwall and with each other, enabling the learners and teacher to think together with the material. In this way, Talkwall is not a tool that provides the background context for dialogue, but its 'voice' is brought directly into the dialogue as part of an agentic intra-action. 


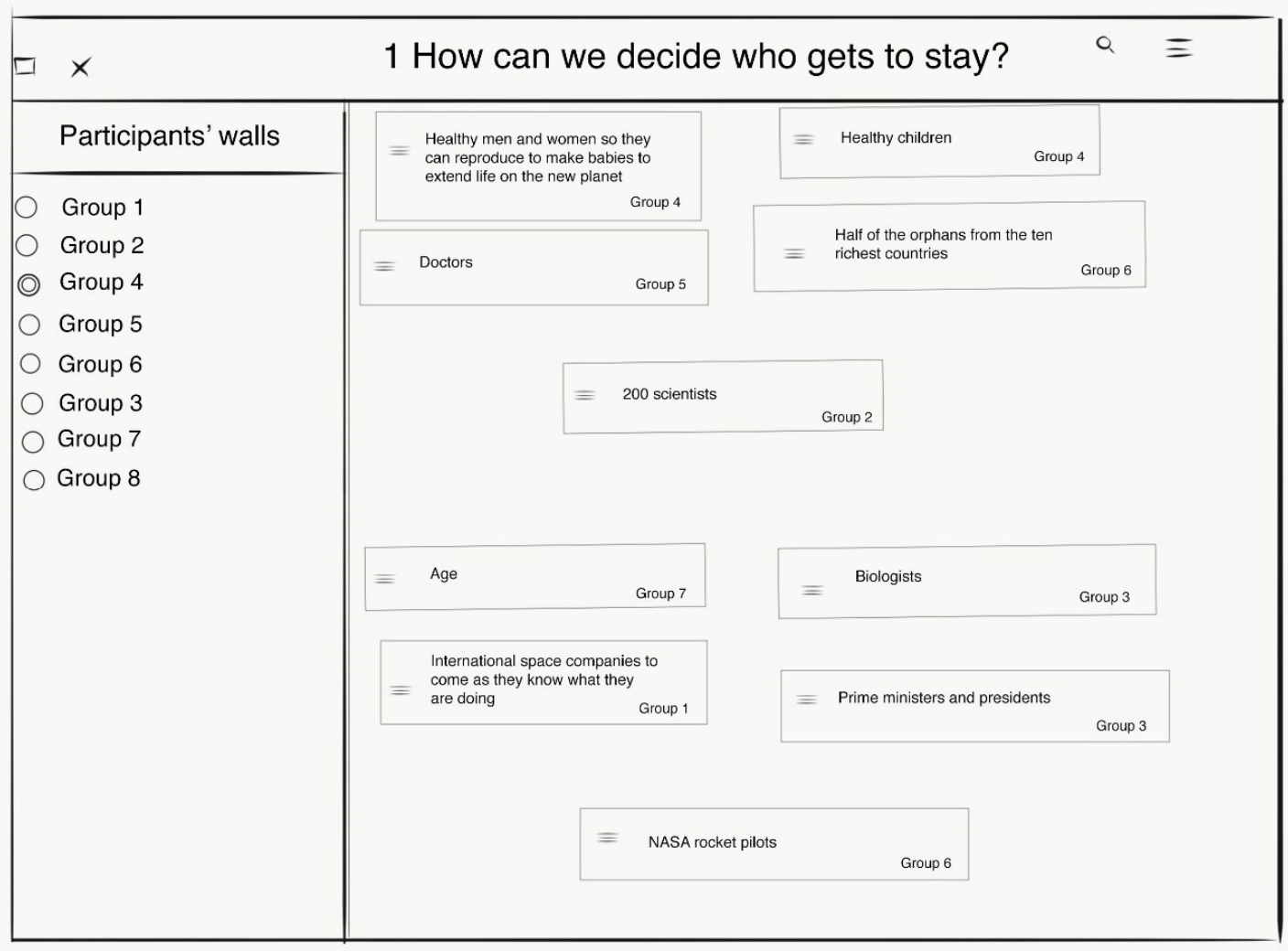

Figure 3. TALK on an interactive classroom screen (representation from a screenshot of a from video-recorded lesson)

Here, we have used one instance from our wider micro-analysed data to show how the relationship between the teacher's DIs relate to student uptake of these intentions in their independent group tasks. We have further illustrated how Talkwall can act to stimulate, mediate and develop group talk in relation to these intentions. In the discussion we return to our research questions and consider the issues raised in our analysis.

\section{Discussion}

\subsection{Working with dialogic intentions}


The work for this paper has been guided by three core research questions. These focus on the ways in which lesson DIs are given prominence by teachers, how they taken up by students and guide dialogue in semi-autonomous group work, and how a microblogging tool might be involved as an active tool in that dialogue. The teacher has three core means of determining the nature of the interactions in semi-autonomous group work in classrooms: defining the task; controlling the parameters of the task; and stating the Dls underlying the task. We have acknowledged the reciprocal nature of task definition and interpretation, and it is clear that the parameters of any task are only 'controlled' to the extent that students understand and act upon teacher scaffolds controlling actions. In acknowledging the complex interplay of influences on learning possibilities, the positioning of technology in the 'mix' seems crucial; but the overarching context, of classes working both to institute the use of Talkwall and embed a dialogic ethos, is also critical. What we see in the ways in which teachers state and re-state Dls through their lessons suggests that they are providing contingent support predicated on the perceived dialogic skills and knowledge base of the students. This is quite broad brush, based upon narrowing the dialogic focus of jointly agreed ground rules for talk to define more clearly those particular features of dialogue pertinent to the task. Such contingency has been shown to be an important factor in student uptake and learning (Corno, 2008; Davis \& Miyake, 2004; van de Pol et al., 2018; Wittwer \& Renkl, 2008); and whilst tailoring support on the basis of students' pre-existing knowledge and skills is very far from the only influence on student learning in semi-autonomous groups (see the introduction and Section 4.2), it is a feature of skilled teaching.

Following from this, building DIs into the research lessons, and stating them to students, may be seen as low-level regulation - that is, invitational rather than prescriptive (van de Pol, Volman, Oort \& Beishuizen, 2014). This is precisely because, as we note in Section 3.1, the use of Dls in lessons is contingent on the students' existing and growing dialogic skills and knowledge. Stated DIs in the research classes were thus referencing previously discussed ground rule protocols and 
were intended to give a steer to important features of dialogue that related to group tasks. In this, there was a clear demarcation between those that were generic and specific in character. The specific Dls focused clearly on one or two elements of dialogue, such as providing reasons, challenging ideas or asking questions such as "why do you think that?'. Generic Dls can be seen as more general exhortation to behave in what might be described as a respectful, dialogic manner; interestingly, we found only one example of a lesson where a stated generic DI was not coupled in some way with a statement of more specific DI(s).

This may all seem relatively unremarkable, until it is placed in the context of the fact that a consistent focus on dialogue in classrooms, in England and internationally, remains rare, despite decades of research and professional development (Mercer \& Dawes, 2014: Howe \& Abedin, 2013; Wells \& Arauz, 2006). What we see in this research, and one reason why it might be seen as important, is an exemplification of the various ways in which teachers, in the process of developing a broad dialogic pedagogy in their classrooms, have used Dls to build on previous class work, helping their students focus on key elements of dialogue that seem particularly relevant for given group tasks. In so doing, the teachers are also expressing to their students how important they, as teachers, see this metacognitive component of learning. As Ben suggests in the opening quote of this paper, the impact of this AfL 'feedforward' should not be underestimated. Further, in these research lessons, and because of the context we outline above, the expression of Dls can be seen as part of an on-going reciprocal process engaged in by both the students and the teacher. This recalls the work of James and Pedder (2006) with, in this case, the ultimate aim being the development a shared understanding of the purposes and practices of dialogic interaction.

\subsection{Student uptake of dialogic intentions}


It is worth reflecting on student uptake of Dls in light of a prior, more general reflection on intention and action. In classrooms, evidence of an understanding of task learning intentions often only emerges as the task progresses, and sometimes not at all (Alrø \& Skovsmose, 2004). In other words, a 'tacit awareness' of task expectations 'may or may not be brought into focus on demand' (Black et al., 2006, p.124). Explicitly considering learning intentions in lessons is a means by which the connections between these intentions, student actions and student learning is supposed to be enhanced (Section 2.2). However, in many classrooms, in England at least, the stating of (primarily conceptual) learning intentions has become a rather mechanistic process. As a result, the stating of learning intentions often fails in its aim of closing the gap between the way teachers and learners 'see' the purpose of, and approaches to, learning in the classroom (Black, 1998).

Being clear about intentions for learning behaviour is only likely to be effective if students understand the learning context. As we have already suggested, for Dls to be understood and acted upon by students the establishment of a 'dialogic classroom ethos', and an understanding of strategies for dialogic interaction in group activities, are central for shared understanding and confident action by students.

In this research we worked with teachers to develop classroom environments in which DIs could be understood and acted upon. In this context, the interactions between students in their working groups are interesting. If only generic Dls were to be stated, it would hardly be surprising to see students drawing on their established ground rules for talk with, hopefully, recourse to a range of appropriate dialogue moves in discussions. In our research lessons, however, generic Dls were very rarely stated without parallel specific $\mathrm{DI}(\mathrm{s})$, and the analysed group interactions present a far from linear correspondence between the student use of specific dialogic moves and teacher statements of Dls. Several things seem to be happening here. 
First, as an example, we have seen that elaboration (EL - see Appendix 1) was high in a range of episodes where students were variously asked to share ideas, build on ideas, reason or challenge and question. In this case, it is clear that there are many ways in which a teacher might ask their class to elaborate in their discussions, and the range of Dls used by teachers in our analysed episodes reflects this. The 'high level' code of elaboration encompassed a range of dialogue moves (and associated DIs), with student uptake linked to the various sub-categories of elaboration in the coding scheme. Certainly, no teacher used the high level term 'elaborate' in the DIs, and it seems likely that this term would have had little meaning for the students. In considering Reasoning (RE), other factors were in play, suggesting the interrelationship between specific dialogue moves. Reasoning responses were high in episodes where students were asked specifically to reason, but also in episodes where they were prompted by the stated DI to challenge and/or question. Similarly, Querying (QU) was also associated with being asked to reason and to challenge.

Such cases suggest that stating Dls can not only enable a focus on specific dialogue moves but can focus student attention on the employment of dialogic strategies more generally, at least where a dialogic classroom ethos is encouraged. Just as no discussions are ever purely dialogic in character (Mercer, Wegerif and Dawes, 1999), it seems that the interplay between dialogic elements in group talk is at least as much about a broad alignment with the learning agenda set by the DIs as it is with a focus on their specifics. Thus, despite the rarity of an exact correspondence between dialogue moves and DIs across the data set, we have clear evidence of students working to 'apply and integrate information provided by their teacher into their ongoing work', something that is seen as crucial for student learning (van de Pol, 2018, p.4).

To exemplify some of this, Section 4.2 evidences an apparent differential uptake of DIs (trying to reach agreement, backing up ideas with reasons) by the students. In the first excerpt, Zac is clearly leading the realisation of the DI, to work on 'trying to reach agreement', more than the 
other group members. In trying to reach agreement, four reasons were expressed in this extract, and they were all from Zac; they were all followed by quick agreement from his group. Does this, then, suggest that Zac is a driving force in steering the group's conversations and, ultimately, influencing the groups' realisation of the DI? Or does it suggest that the group are more comfortable with cumulative talk (Mercer, Wegerif \& Dawes, 1999) in this instance? The rapid assent to Zac's suggestions and reasons does not, of course, mean that the other members of the group are not intellectually engaged with the task (in fact, the video evidence suggests otherwise); and it does not bring into question Vygotskian perspectives on social interaction which have led to research showing that 'experience of social reasoning can improve scores on measures of individual reasoning' (Wegerif, Mercer and Dawes, 1999, p.493).

\subsection{Talkwall and dialogue in student groups}

The importance of stating DIs, not just for whole lessons but for framing the focus of specific lesson phases, only emerged for the teachers as the work progressed, and directly as a result of considering the use of technology for dialogic purposes (Warwick, Mercer, Kershner \& Kleine Staarman, 2010; Hennessy, 2011). In the work presented here, teachers planned to focus student attention on specific and generic Dls, employing Talkwall to help students to develop 'interthinking' (Littleton \& Mercer, 2013) during dialogic phases of the lesson.

Talkwall was a locus of attention for encouraging the development of dialogic interactions in student group work, in addition to assisting the collective knowledge building that might be expected through such work (Rasmussen \& Ludvigsen, 2010; Scardamalia \& Bereiter, 1994). To understand how Talkwall is implicated in the uptake of teachers' intentions for spoken dialogue we have applied a material-dialogic framework proposed by Hetherington et al. (2018). Using this approach to theorise dialogic relations with materials enables us to foreground the voice of the technology in the dialogue as meaning-making emerges through the agentic intra-action of the 
teacher, students and Talkwall. We have seen how Talkwall contributions 'push themselves' into the dialogue and, in so doing, Talkwall becomes an active participant in the learning that is taking place, enabling students to learn with Talkwall as material-dialogic space is both widened and deepened (Wegerif, 2006, 2007). Talkwall's active role within educational dialogues is perhaps most sharply brought into focus when we consider how its affordances, enacted through students' dialogic intra-action with the tool, may facilitate a form of dialogue between the students and Talkwall that, in turn, can facilitate students' uptake of Dls.

How the students enacted the affordances of the tool to assist dialogue and collective understanding was determined partly by the parameters of the task. For example, the specific problem (e.g. in our presented episode, who might be given a place on a spaceship in a scenario where Earth was threatened by a giant asteroid) determined what was to be discussed. In terms of controlling the parameters of the task, teachers would conventionally define the 'end product' expected on the group walls, though usually in quite broad terms that would draw the students into dialogue around their ideas; thus, they might specify the need for the creation of a hierarchical list, lists of positive and negative features, evidence of building on the views of another group, etc. In considering how the enacted affordances of the tool meshed with group talk, the openendedness of such requirements, and the open, speculative nature of many tasks seemed central to encouraging dialogic interaction.

Several other conclusions seem pertinent. Firstly, through intra-action with another group's ideas the enacted affordance of browsing widens the material-dialogic space, as students are privy to a far wider range of ideas and possibilities than they would be when working as a 'conventional' group in a classroom. In all of our examined episodes, we therefore have examples of students engaging with the ideas of other groups within the class. In some cases, focus on particular contributions whilst browsing demonstrated the human tendency towards confirmation bias (Nickerson, 1998). However, we also saw instances where the material-dialogic space was 
deepened as the framing grounds of other group's contributions were questioned, or where contributions were selected that caused a level of disagreement amongst group members. Thus, support for, or challenge to, the ideas of group members may be found through browsing contributions (which can simultaneously act as an assistive memory). This use of the tool, however, should remind us of how such activity is only likely in classrooms where a dialogic ethos is promoted, giving students confidence that it is legitimate to discuss and question the ideas of others. Selection during browsing requires assessment and the providing of a justification or reason, and though we found a few instances of students trying to impose an idea through selection, the dialogue usually suggested student uptake of the need to justify choices; this strong focus within the DIs therefore seems clearly evidenced in student talk.

As in our previous research on interactive whiteboards (Warwick et al., 2010; Mercer et al., 2017), provisionality and positioning seem particularly important in enabling students to explore the material-dialogic space (though other affordances act in combination to achieve the same effect). Group members can tentatively place contributions, their own or those of others, in specific places on the wall, and discuss their placing as appropriate or not in line with the broad task requirements. Positioning is always provisional, with changes possible as ideas are queried through the dialogue; and it differs from the more general justification of contribution selection, in that, usually, placement is in relation to other ideas.

Through the enactment of such affordances, Talkwall was intimately implicated in the uptake of DIs, however 'messy' the reality of such uptake. More generally, we have shown that DIs are only one link in the chain of enabling students to become more dialogic. Any learning intentions for a lesson are actually quite limited in relation to the range of skills, metacognitive or otherwise, a student may employ during a lesson; they are intended to focus the student on key aspects of the task in hand, not on all the skills associated with the task. They are employed in 
combination with careful task design by the teacher, and we have implied that design contingent on the pre-existing knowledge of skills of students is more likely to enable students to align their interpretation of the task with that of the teacher. Lastly, they allow a greater understanding of the place of technology in achieving specified teaching and learning outcomes, where that technology is seen as the servant of pedagogy.

\subsection{Addendum}

Here, we wish to return to an unanswered question. Earlier in this paper we raised the issue of the lack of evidence of dialogic coordination in student groups. In Section 4.2 we showed how the actions of the teacher after the group activity provided evidence of dialogic coordination, in terms of the coding scheme (Appendices $4 \& 5$ ). Dialogic coordination is very tightly defined by our coding scheme, a tightness necessary for establishing reliability of the scheme in the overall project. However, we would suggest that the apparent lack of evidence of coordination by students may be a function of this tightly prescribed definition of dialogue moves. It may be that loosening this definition, particularly when examining the content of Talkwall posts, could yield evidence of dialogic activity that appears not to be present. As we embark on this endeavour, we are hoping that this hypothesis is supported by the data.

\section{Acknowledgements}

The DiDiAC research project is funded by the Research Council of Norway [FINNUT/Project No: 254761] and is registered and approved by the Norwegian data protection service (NSD):

\section{http://www.nsd.uib.no/personvernombud/en/notify/index.html}


We particularly wish to thank the teachers and students that took part in the project for their willing and active involvement.

\section{References}

Alexander, R. (2008). Towards dialogic teaching: Rethinking classroom talk (4th ed.).

Dialogos.

Alexander, R. J. (2017a). Towards Dialogic Teaching: rethinking classroom talk (5th ed.), Dialogos.

Alexander R. J. (2017b). 'Developing Dialogue: process, trial, outcomes', paper for the 17th international conference of EARLI, Finland. http://www. robinalexander.org.uk/wp-content/uploads/2017/08/ EARLI-2017-paper-170825.pdf

Alrø, H., \& Skovsmose, O. (2004). Dialogue and learning in mathematics education: Intention, reflection, critique. Mathematics Education Library, Vol. 29. New York, NY: Springer

Ames, C. (1992). Classrooms: Goals, structures, and student motivation. Journal of Educational Psychology, 84(3), 261-271. https://doi.org/10.1037/0022$\underline{0663.84 .3 .261}$

Arvaja, M., Häkkinen, P., \& Kankaanranta, M. (2008). Collaborative learning and computer-supported collaborative learning environments. In J. Voogt, \& G. Knezek (Eds.) International handbook of information technology in primary and secondary education. Boston, MA: Springer. (pp. 267-279) 
Baines, E., Blatchford, P., \& Chowne, A. (2007). Improving the effectiveness of collaborative group work in primary schools: Effects on science attainment. British Educational Research Journal, 33(5), 663.

Baird, J-A., Hopfenbeck, T.N., Newton, P., Stobart, G. \& Steen-Utheim, T.M. (2014). Assessment and Learning: State of the Field Review. Oxford University Centre for Educational Assessment Report OUCEA/14/2.

Bakhtin, M. (1986). Speech genres and other late essays. (V. W. McGee, Trans.). Austin, TX: University of Texas Press.

Barnes, D. (1976). From communication to curriculum. Harmondsworth: Penguin Books.

Barad, K. (2007). Meeting the universe half-way: Quantum physics and the entanglement of matter and meaning. Durham: Duke University Press.

Barron, B. (2003). When Smart Groups Fail. Journal of the Learning Sciences, 12(3), 307-359. https://doi.org/10.1207/S15327809JLS12031

Beauchamp, G. (2011) 'Interactivity and ICT in the primary school: categories of learner interactions with and without ICT', Technology, Pedagogy and Education, 20, 175190 (DOI: 10.1080/1475939X.2011.588408)

Beauchamp. G. \& Kennewell, S. (2008). The influence of ICT on the interactivity of teaching. Education and Information Technologies, 13(4), 305-315

BERA (2018) Ethical Guidelines for Educational Research, 4th. Edition. Retrieved from: https://www.bera.ac.uk/wp-content/uploads/2018/06/BERA-Ethical-Guidelines-forEducational-Research 4thEdn 2018.pdf?noredirect=1 
Black, P. (1998). Formative assessment: raising standards inside the classroom. School Science Review, 80(291), 39-46.

Black, P. (2015). Assessment: Friend or Foe of Pedagogy and Learning. In Feuer, M.J., Berman, A.I. \& Atkinson, R.C. (Eds), Past as Prologue: the National Academy of Education at 50 - Members Reflect. Washington, DC: National Academy of Education. p235-242. Accessed at: https://naeducation.org/wp-content/uploads/2016/11/NAEd-50th-anniversarybookmarks-11-18-15.pdf\#page=254

Black, P., McCormick, R., James, M., \& Pedder, D. (2006). Learning How to Learn and Assessment for Learning: a theoretical inquiry. Research Papers in Education, 21, $119-132$.

Black, P., \& Wiliam, D. (2009). Developing the theory of formative assessment. Educational Assessment, Evaluation and Accountability, 21(1), 5-31.

Bower, M. (2008). Affordance analysis - matching learning tasks with learning technologies. Educational Media International, 45(1), 3-15. https://doi.org/10.1080/09523980701847115

Clarke, S. N., Howley, I., Resnick, L., \& Penstein Rosé, C. (2016). Student agency to participate in dialogic science discussions. Learning, Culture and Social Interaction, 10, 27-39. https://doi.org/10.1016/j.Icsi.2016.01.002

Coltman, P., Warwick, J., Wilmott, J., Pino Pasternak, D. \& Whitebread, D. (2013) Teachers co-constructing pedagogical practices to support children's exploratory talk and self-regulation: the Children Articulating Thinking (ChAT) project. In D. Whitebread, N. Mercer, C. Howe \& A. Tolmie (Eds.). Self-regulation and dialogue 
in primary classrooms. British Journal of Educational Psychology Monograph Series II: Psychological Aspects of Education - Current Trends, No. 10. (pp. 127146). Leicester: BPS.

Cook, V., Warwick, P., Vrikki, M., Major, L \& Wegerif, R. (2019). Developing materialdialogic space in geography learning and teaching: combining a dialogic pedagogy with the use of a microblogging tool. Thinking Skills and Creativity, 31, 217-231

Corno, L. (2008). On teaching adaptively. Educational Psychologist, 43(3), 161-173. doi:10.80/00461520802178466

Davis, E. A., \& Miyake, N. (2004). Explorations of scaffolding in complex classroom systems. Journal of the Learning Sciences, 13(3), 265-272. doi:10.1207/s15327809jls1303_1

Crichton, H., \& McDaid, A. (2016). Learning intentions and success criteria: learners' and teachers' views. The Curriculum Journal, 27(2), 190-203. https://doi.org/10.1080/09585176.2015.1103278

Dweck, C. S. (2000). Self-theories: Their Role in Motivation, Personality, and Development. Philadelphia, PA: Psychology Press.

Dweck, C.S. (2012). Self-theories motivate self-regulated learning. In D.H. Schunk \& B.J. Zimmerman (Eds). Motivation and Self-Regulated Learning: Theory, Research, and Applications. Abingdon:Routledge.

EEF. (2017). Dialogic Teaching - Evaluation report and executive summary. Education Endowment Foundation. Available online: 
https://educationendowmentfoundation.org.uk/public/files/Projects/Evaluation Rep orts/Dialogic Teaching Evaluation Report.pdf

Flick, L. B., \& Dickinson, V. L. (1997). Teacher Intentions, Teaching Practice, and Student Perceptions of Inquiry-Oriented Teaching. Retrieved from https://eric.ed.gov/?id=ED407254

Gao, F., Luo, T., \& Zhang, K. (2012). Tweeting for learning: A critical analysis of research on microblogging in education published in 2008-2011. British Journal of Educational Technology, 43(5), 783-801. https://doi.org/10.1111/j.14678535.2012.01357.x

Geertz, C. (2008). Thick Description: Toward an Interpretive Theory of Culture. In Oakes, T., \& Price, P. L. (eds) The Cultural Geography Reader (pp. 29-39). Abingdon: Routledge. https://doi.org/10.4324/9780203931950-11

Gibson, J.J. (1977). The theory of affordances. In R. Shaw \& J. Bransford (Eds.) Perceiving, acting and knowing: Toward an ecological psychology (pp.67-82). Hillsdale: NJ, Lawrence Erlbaum Associates.

Gibson, J.J. (1979). The Ecological Approach to Visual Perception. Boston: Houghton Mifflin.

Hakkarainen, K. (2009). A knowledge-practice perspective on technology-mediated learning. International Journal of Computer-Supported Collaborative Learning, 4(2), 213-231. 
Hartson, R. (2003). Cognitive, physical, sensory, and functional affordances in interaction design. Behaviour \& Information Technology, 22(5), 315-338. https://doi.org/10.1080/01449290310001592587

Haßler, B., Major, L., \& Hennessy, S. (2016). Tablet use in schools: A critical review of the evidence for learning outcomes. Journal of Computer Assisted Learning, 32(2), $139-156$

Hennessy, S. (2011). The role of digital artefacts on the interactive whiteboard in supporting classroom dialogue. Journal of Computer Assisted Learning, 27(6), 463-489.

Hennessy, S., Rojas-Drummond, S., Higham, R., Márquez, A. M., Maine, F., Ríos, R. M., García-Carrión, R., Torreblanca, O. \& Barrera, M. J. (2016). Developing a coding scheme for analysing classroom dialogue across educational contexts. Learning, Culture and Social Interaction, 9, 16-44.

Hetherington, L., Hardman, M., Noakes, J., \& Wegerif, R. (2018). Making the case for a material-dialogic approach to science education. Studies in Science Education, 54(2), 141-176.

Hetherington, L., \& Wegerif, R. (2018). Developing a material-dialogic approach to pedagogy to guide science teacher education. Journal of Education for Teaching, $1-17$.

House of Commons Children, Schools and Families Committee (2008) Testing and Assessment. Third Report of Session 2007-08. Volume I. London, The Stationery Office Limited 
Howe, C., and Abedin, M. (2013). "Classroom dialogue: A systematic review across four decades of research." Cambridge Journal of Education 43 (3): 325-356.

Hutchby, I. (2001). Technologies, texts and affordances. Sociology, 35 (2), 441-456

James, M., \& Pedder, D. (2006). Beyond method: assessment and learning practices and values. The Curriculum Journal, 17(2), 109-138.

Jordan, B., \& Henderson, A. (1995). Interaction analysis: Foundations and practice. The Journal of the Learning Sciences, 4, 39-103.

Kirschner, P. (2002). Can we support CCSL? Educational, social and technological affordances. Available from Paul Kirschner at Researchgate.net

Kuhn, D. (1991). The skills of argument. Cambridge University Press.

Kuhn, D. (2015). Thinking together and alone. Educational Researcher, 44(1), 46-53. doi.org/10.3102/0013189X15569530

Kuhn, D. (2016). A role for reasoning in a dialogic approach to critical thinking. Topoi, 1-8. doi.org/10.1007/s11245-016-9373-4

Kutnick, P., Sebba, J., Blatchford, P., Galton, M., \& Thorpe, J. (2005). The Effects of Pupil Grouping: Literature Review (Research Report 688 No. 688). Nottingham: DfES Publications.

Lantz-Andersson, A., Linderoth, J., \& Säljö, R. (2009). What's the problem? Meaning making and learning to do mathematical word problems in the context of digital tools. Instructional Science, 37(4), 325-343. 
Littleton, K., \& Mercer, N. (2013). Interthinking: putting talk to work. Abingdon, Oxon : Routledge.

Magnusson, T. (2010). Designing constraints: Composing and performing with digital musical systems. Computer Music Journal, 34(4), 62-73.

Major, L., Warwick, P., Rasmussen, I., Ludvigsen, S., \& Cook, V. (2018). Classroom dialogue and digital technologies: A scoping review. Education and Information Technologies; New York, 1-34. http://dx.doi.org/10.1007/s10639-018-9701-y

Major, L. \& Warwick, P. (2019) 'Affordances for dialogue': the role of digital technology in supporting productive classroom talk. In N. Mercer, R. Wegerif, \& L. Major (Eds). The Routledge International Handbook of Research on Dialogic Education. Routledge. pp. 394-410

Marcos, J. J. M., \& Tillema, H. (2006). Studying studies on teacher reflection and action: An appraisal of research contributions. Educational Research Review, 1(2), 112132. https://doi.org/10.1016/i.edurev.2006.08.003

Marshall, J. C., Smart, J., \& Alston, D. M. (2016). Development and validation of Teacher Intentionality of Practice Scale (TIPS): A measure to evaluate and scaffold teacher effectiveness. Teaching and Teacher Education, 59, 159-168. https://doi.org/10.1016/j.tate.2016.05.007

McManus, S. (2008). Attributes of effective formative assessment. Washington, DC: Council for Chief State School Officers. doi.org/ 10.1080/0969594X.2010.513678

Mercer, N. (1995). The Guided Construction of Knowledge: talk amongst teachers and learners. Clevedon: Multilingual Matters 
Mercer, N. (1996) The quality of talk in children's collaborative activity in the classroom. Learning and Instruction, 6(4), 359-377

Mercer, N. (2013). The social brain, language, and goal-directed collective thinking: A social conception of cognition and its implications for understanding how we think, teach, and learn. Educational Psychologist, 48(3), 148-168. doi.org/10.1080/00461520.2013.804394

Mercer, N. \& Dawes, L. (2008). The value of Exploratory Talk. In Mercer, N. \& Hodgkinson, S. (2008) (eds) Exploring Talk in School. London: Sage.

Mercer, N., \& Dawes, L. (2014). The study of talk between teachers and students, from the 1970s until the 2010s. Oxford Review of Education, 40(4), 430-445. https://doi.org/10.1080/03054985.2014.934087

Mercer, N., Dawes, L., Wegerif, R., \& Sams, C. (2004). Reasoning as a scientist: ways of helping children to use language to learn science. British Educational Research Journal, 30(3), 359-377.

Mercer, N., Fernandez, M., Dawes, L., Wegerif, R., \& Sams, C. (2003). Talk about texts at the computer: using ICT to develop children's oral and literate abilities. Reading, 37(2), 81-89.

Mercer, N., Hennessy, S., \& Warwick, P. (2017). Dialogue, thinking together and digital technology in the classroom: Some educational implications of a continuing line of inquiry. International Journal of Educational Research. Available online: https://doi.org/10.1016/j.ijer.2017.08.007 
Mercer, N., Wegerif, R., and Dawes, L. (1999). Children's Talk and the Development of Reasoning in the Classroom. British Educational Research Journal, 1, 95-111.

Midgley, C., Kaplan, A., \& Middleton, M. (2001). Performance-approach goals: Good for what, for whom, under what circumstances, and at what cost? Journal of Educational Psychology, 93(1), 77-86. https://doi.org/10.1037/0022-0663.93.1.77

Mortimer, E., \& Scott, P. (2003). Meaning making in secondary science classrooms. Buckingham: Open University Press.

Muhonen, H., Pakarinen, E., Poikkeus, A.-M., Lerkkanen, M.-K., \& Rasku-Puttonen, H. (2018). Quality of educational dialogue and association with students' academic performance. Learning and Instruction, 55, 67-79.

Newman, D., Griffin, P., \& Cole, M. (1989). The construction zone: Working for cognitive change in school. Cambridge University Press.

Nickerson, R. S. (1998). Confirmation Bias: A Ubiquitous Phenomenon in Many Guises. Review of General Psychology, 2(2), 175-220. https://doi.org/10.1037/1089$\underline{2680.2 .2 .175}$

Nystrand, M., A. Gamoran, R. Kachur, and C. Prendergast. (1997). Opening Dialogue: Understanding the Dynamics of Language and Learning in the English Classroom. New York, NY: Teachers College Press.

Oliver, M. (2005). The Problem with Affordance. E-Learning and Digital Media, 2(4), 402-413. https://doi.org/10.2304/elea.2005.2.4.402

Osborne, D. R. (2014). An ecological approach to educational technology: affordance as a design tool for aligning pedagogy and technology. Exeter University, UK. 
Available online at: https://ore.exeter.ac.uk/repository/handle/10871/16637

(Accessed March 2018)

Pedder, D. (2006). Organisational conditions that foster successful classroom promotion of Learning How to Learn. Research Papers in Education, 21, 2, 171-200

Pifarré, M., \& Kleine Staarman, J. (2011). Wiki-supported collaborative learning in primary education: How a dialogic space is created for thinking together. International Journal of Computer-Supported Collaborative Learning, 6(2), 187-205. https://doi.org/10.1007/s11412-011-9116-x

Pressley, M. and Harris, K. R. (2006) 'Cognitive strategy instruction: from basic research to classroom instruction', in P. A. Alexander and P. Winne (eds), Handbook of Educational Psychology (2nd edn), Mahwah, NJ: Erlbaum (pp. 265-286).

Rajala, A., \& Sannino, A. (2015). Students' deviations from a learning task: An activitytheoretical analysis. International Journal of Educational Research, 70, 31-46.

Rasmussen, I., Krange, I., \& Ludvigsen, S. R. (2003). The process of understanding the task: how is agency distributed between students, teachers and representations in technology-rich learning environments? International Journal of Educational Research, 39(8), 839-849.

Rasmussen, I. \& Hagen, A. M. M. (2015). Facilitating students' individual and collective knowledge construction through microblogs. International Journal of Educational Research, 72, 149- 161 
Rasmussen, I., \& Ludvigsen, S. (2010). Learning with computer tools and environments: A sociocultural perspective. International Handbook of Psychology in Education, 399-435.

Rojas-Drummond, S.M., Albarrán, C.D., \& Littleton, K.S. (2008). Collaboration, creativity and the co-construction of oral and written texts. Thinking Skills and Creativity, 3, $177-191$.

Rojas-Drummond, S. M., Littleton, K., Hernández, F. \& Zúñiga, M. (2010). Dialogical interactions among peers in collaborative writing contexts. In C. Howe \& K. Littleton (Eds.), Educational dialogues: Understanding and promoting productive interaction (pp.128-148). London: Routledge.

Säljö, R. (1995). Mental and physical artifacts in cognitive practices. In P. Reimann, \& H. Spada (Eds.). Learning in humans and machines: Towards an interdisciplinary learning science (pp. 83-96). Oxford: Pergamon.

Scardamalia, M., \& Bereiter, C. (1994). Computer support for knowledge-building communities. The Journal of the Learning Sciences, 3(3), 265-283.

Schwarz, B. B., \& Baker, M. J. (2016). Dialogue, argumentation and education: History, theory and practice. Cambridge: Cambridge University Press.

Sfard, A. (2008). Thinking as communicating: Human development, the growth of discourses and mathematizing. Cambridge: Cambridge University Press.

Singleton, S. (2016). The effect of microblogging on middle school student engagement and critical thinking (PhD Thesis). Liberty University. Available online at: https://digitalcommons.liberty.edu/doctoral/1178/ (Accessed March 2018) 
Slavin, R. E. (1987). Mastery learning reconsidered. Review of Educational Research, 57, $175-213$

Stahl, G., Cress, U., Ludvigsen, S. \& Law, N. (2014). Dialogic foundations of CSCL. International Journal of Computer-Supported Collaborative Learning, 9(2), 117125. doi.org/10.1007/s11412-014-9194-7

Tsang, W. K. (2004). Feedback and Uptake in Teacher-Student Interaction: An Analysis of 18 English Lessons in Hong Kong Secondary Classrooms, RELC Journal, 35(2), 187-209.

Turner, P. (2005). Affordance as context. Interacting with Computers, 17(6), 787-800. https://doi.org/10.1016/j.intcom.2005.04.003

van de Pol, J., Volman, M., Oort, F., \& Beishuizen, J. (2014). Teacher scaffolding in small- group work: An intervention study. Journal of the Learning Sciences, 23(4), 600-650. doi:10.1080/10508406.2013.805300

van de Pol, J., Mercer, N., \& Volman, M. (2018). Scaffolding Student Understanding in Small-Group Work: Students' Uptake of Teacher Support in Subsequent SmallGroup Interaction. Journal of the Learning Sciences, p1-34. Available online: https://doi.org/10.1080/10508406.2018.1522258

Vandergrift, L., Goh, C., Mareschal, C., \& Tafaghodtari, M. (2006). The Metacognitive Awareness Listening Questionnaire: Development and validation. Language Learning, 53(3), 431-462. 
Vrikki, M., Wheatley, L., Howe, C., Hennessy, S., \& Mercer, N. (2018). Dialogic practices in primary school classrooms. Language and Education, 1-19. Available online: https://doi.org/10.1080/09500782.2018.1509988

Vyas, D., Chisalita, C. M. \& van der Veer, G. C. (2006) Affordance in interaction. In Grote, G. (Ed.) Proceedings of the 13th European Conference on Cognitive Ergonomics : Trust and Control in Complex Socio-technical Systems, ACM Press, ETHZ, Zürich, Switzerland, pp. 92-99. Accessed online 24 June 2018: https://eprints.qut.edu.au/69903/1/AffordancelnInteraction-ECCE13-

\section{CameraReady.pdf}

Vygotsky, L. 1962. Thought and Language. Cambridge, MA: MIT.

Warwick, P., Mercer, N., Kershner, R., \& Staarman, J. K. (2010). In the mind and in the technology: The vicarious presence of the teacher in pupil's learning of science in collaborative group activity at the interactive whiteboard. Computers \& Education, 55(1), 350-362.

Wegerif, R. (2006). A dialogic understanding of the relationship between CSCL and teaching thinking skills. International Journal of Computer-Supported Collaborative Learning, 1(1), 143-157.

Wegerif, R. (2013). Dialogic: Education for the Internet age. London: Routledge.

Wegerif, R., Mercer, N., and Dawes, L. (1999) From social interaction to individual reasoning: an empirical investigation of a possible socio-cultural model of cognitive development. Learning and Instruction. 493-516. 
Wells, G. and R. M. Arauz. 2006. "Dialogue in the classroom." The Journal of the Learning Sciences 15 (3): 379-428.

Whitebread, D. \& Coltman, P. (2010) 'Aspects of pedagogy supporting metacognition and self-regulation in mathematical learning of young children: evidence from an observational study', ZDM Mathematics Education, 42 (2), 163-178 https://doi. org/10.1007/s11858-009-0233-1

Whitebread, D., Mercer, N., Howe, C. \& Tolmie, A. (Eds.) (2013). Self-regulation and dialogue in primary classrooms. British Journal of Educational Psychology Monograph Series II: Psychological Aspects of Education - Current Trends, No. 10. Leicester: BPS.

Wittwer, J., \& Renkl, A. (2008). Why instructional explanations often do not work: A framework for understanding the effectiveness of instruction explanations. Educational Psychologist, 43(1), 49-64. 


\begin{tabular}{lll}
\hline CODES & DEFINITION & KAPPA \\
\hline
\end{tabular}

Invite elaboration Invites building on, elaboration, evaluation, clarification of own or another's contribution.

Elaboration (EL)

Builds on, elaborates, evaluates, clarifies own or other's contribution. This adds substantive new information or a new perspective beyond anything said in previous turns, even by a word.
Invite reasoning Explicitly invites explanation, (REI) justification of a contribution or speculation (new scenarios), prediction or hypothesis.

Reasoning (RE) Provides an explanation or .77 justification of own or another's contribution. It also includes drawing on evidence.
Querying (QU) Doubting, full/partial disagreement, challenging or rejecting a statement.

Coordination (CO) $\begin{aligned} & \text { Synthesises or summarises } \\ & \text { collective ideas (including own and }\end{aligned}$ others' ideas). Proposes a resolution or consensus view after discussion.

\footnotetext{
${ }^{2}$ Non-calculable due to lack of variation
} 

Appendix 2: Dialogue move frequencies of 29 groupwork-process episodes

\begin{tabular}{|c|c|c|c|c|c|c|c|c|c|}
\hline & Lesson ID & Subject & $\begin{array}{l}\text { Episode in } \\
\text { the lesson }\end{array}$ & ELI & EL & REI & RE & QU & $\mathrm{CO}$ \\
\hline 1 & ID03 & English & 3 & 1 & 1 & 0 & 2 & 1 & 0 \\
\hline $2^{*}$ & ID04 & Science & 2 & 7.5 & 13.0 & 1.5 & 5.0 & 11.0 & 0.0 \\
\hline 3 & ID04 & Science & 4 & 2 & 6 & 1 & 1 & 3 & 0 \\
\hline 4 & ID05 & Science & 4 & 0 & 0 & 0 & 3 & 1 & 0 \\
\hline 5 & ID06 & Science & 2 & 0 & 3 & 1 & 2 & 1 & 0 \\
\hline 6 & ID06 & Science & 5 & 0 & 4 & 0 & 3 & 0 & 0 \\
\hline 7 & ID07 & Geography & 1 & 1 & 15 & 0 & 3 & 1 & 0 \\
\hline 8 & ID07 & Geography & 2 & 1 & 5 & 0 & 3 & 1 & 0 \\
\hline 9 & ID07 & Geography & 3 & 0 & 9 & 0 & 2 & 5 & 0 \\
\hline 10 & ID08 & Geography & 1 & 4 & 13 & 0 & 6 & 2 & 0 \\
\hline 11 & ID08 & Geography & 2 & 0 & 1 & 0 & 1 & 0 & 0 \\
\hline 12 & ID08 & Geography & 4 & 10 & 15 & 0 & 5 & 5 & 0 \\
\hline 13 & ID10 & English & 4 & 0 & 10 & 1 & 10 & 10 & 0 \\
\hline 14 & ID12 & Geography & 2 & 1 & 6 & 1 & 7 & 4 & 0 \\
\hline 15 & ID13 & Geography & 1 & 1 & 8 & 4 & 6 & 0 & 0 \\
\hline 16 & ID13 & Geography & 2 & 1 & 9 & 3 & 3 & 2 & 0 \\
\hline 17 & ID14 & Geography & 1 & 0 & 2 & 0 & 3 & 0 & 0 \\
\hline 18 & ID14 & Geography & 3 & 1 & 14 & 0 & 4 & 5 & 0 \\
\hline 19 & ID14 & Geography & 4 & 1 & 10 & 2 & 12 & 6 & 0 \\
\hline 20 & ID14 & Geography & 6 & 0 & 6 & 2 & 3 & 3 & 0 \\
\hline 21 & ID15 & Science & 2 & 0 & 0 & 0 & 1 & 1 & 0 \\
\hline 22 & ID16 & Science & 1 & 0 & 5 & 0 & 1 & 2 & 0 \\
\hline 23 & ID16 & Science & 3 & 0 & 6 & 2 & 10 & 2 & 0 \\
\hline 24 & ID16 & Science & 5 & 2 & 4 & 2 & 2 & 1 & 0 \\
\hline 25 & ID16 & Science & 7 & 3 & 12 & 2 & 3 & 5 & 0 \\
\hline 26 & ID17 & Science & 1 & 1 & 4 & 0 & 1 & 0 & 0 \\
\hline 27 & ID17 & Science & 3 & 1 & 3 & 0 & 2 & 3 & 0 \\
\hline
\end{tabular}




\begin{tabular}{|l|l|l|l|l|l|l|l|l|l|}
28 & ID17 & Science & 5 & 0 & 7 & 0 & 4 & 1 & 0 \\
\hline 29 & ID17 & Science & 7 & 0 & 11 & 2 & 1 & 0 & 0 \\
\hline
\end{tabular}

*This episode was drawn from episodes that were double coded for reliability. Instead of choosing the coding of one coder to present in the table, we show the average of both coders. 
Appendix 3: Definition of enacted affordances

\begin{tabular}{|c|c|}
\hline $\begin{array}{l}\text { Enacted } \\
\text { affordance }\end{array}$ & Enables \\
\hline Browsing & Review of contributions (possibly with subsequent action). \\
\hline Selection & $\begin{array}{l}\text { Contribution selection (possibly as a basis for dialogue, where it is } \\
\text { often strongly linked to elaboration and reasoning). }\end{array}$ \\
\hline Positioning & $\begin{array}{l}\text { Orientation/arranging/prioritisation of contributions in relation to } \\
\text { task requirements (e.g. split screen). Use of hashtags to categorise } \\
\text { posts. }\end{array}$ \\
\hline $\begin{array}{l}\text { Support/ } \\
\text { Challenge }\end{array}$ & $\begin{array}{l}\text { Group member may find support for position, or have position } \\
\text { challenged, from contributions rather than from within group. }\end{array}$ \\
\hline Provisionality & $\begin{array}{l}\text { Tentative selection or positioning of items indicates possible } \\
\text { intention, which may be modified on the basis of } \\
\text { challenge/dialogue. } \\
\text { The ability to edit posts may also make a post provisional. }\end{array}$ \\
\hline Assistive memory & $\begin{array}{l}\text { Less reliance on/externalisation of working memory. } \\
\text { Revisiting/reference back to previous contributions. A potential } \\
\text { source of evidence. }\end{array}$ \\
\hline Control & $\begin{array}{l}\text { Deliberate manipulation by the teacher/talkwall leader to delimit or } \\
\text { manipulate the activity. This includes the choice of wall titles, } \\
\text { backgrounds, and the ability to delete other people's posts. Includes } \\
\text { focusing, via magnification and filter functions, to create an object } \\
\text { of attention (potentially for dialogue to emerge around it). May } \\
\text { occur prior to, or after, selection and positioning. }\end{array}$ \\
\hline
\end{tabular}


Appendix 4: Summary of 7 episodes - relating $\mathrm{DI}$, dialogue moves and affordances

\begin{tabular}{|c|c|c|c|c|c|c|c|c|c|c|c|c|c|c|c|c|c|c|}
\hline $\begin{array}{l}\text { Episode } \\
\text { number }\end{array}$ & $\begin{array}{l}\text { Lesson } \\
\text { ID }\end{array}$ & Subject & $\begin{array}{l}\text { Episode } \\
\text { in the } \\
\text { lesson }\end{array}$ & ELI & EL & REI & $\mathrm{RE}$ & QU & $\mathrm{CO}$ & BROW & SEL & POS & SUPP & PROV & $\mathrm{AM}$ & CONT & Specific DI & Generic DI \\
\hline 2 & ID04 & Sci & 2 & 6 & 14 & 2 & 5 & 13 & 0 & $\checkmark$ & $\checkmark$ & $\checkmark$ & $\checkmark$ & & $\checkmark$ & & $\begin{array}{l}\text { To share ideas, } \\
\text { listen and respond } \\
\text { to each other. } \\
\text { To try to reach } \\
\text { agreement } \\
\text { (justifying } \\
\text { reasons \& making } \\
\text { decisions) }\end{array}$ & \\
\hline 14 & ID12 & Geog & 2 & 1 & 6 & 1 & 7 & 4 & 0 & & & & & $\checkmark$ & $\checkmark$ & $\checkmark$ & $\begin{array}{l}\text { To ask each other } \\
\text { 'why do you think } \\
\text { that?' }\end{array}$ & $\begin{array}{l}\text { To be able } \\
\text { to work } \\
\text { together as } \\
\text { a group to } \\
\text { discuss } \\
\text { ideas }\end{array}$ \\
\hline 15 & ID13 & Geog & 1 & 1 & 8 & 4 & 6 & 0 & 0 & $\checkmark$ & & & & $\checkmark$ & & $\checkmark$ & \multirow{2}{*}{$\begin{array}{l}\text { To share } \\
\text { (geographical) } \\
\text { ideas and to ask } \\
\text { each other to back } \\
\text { up ideas with } \\
\text { reasons }\end{array}$} & \\
\hline 16 & ID13 & Geog & 2 & 1 & 9 & 3 & 3 & 2 & 0 & & $\checkmark$ & & & $\checkmark$ & $\checkmark$ & $\checkmark$ & & \\
\hline 18 & ID14 & Geog & 3 & 1 & 14 & 0 & 4 & 5 & 0 & $\checkmark$ & & & & & & & \multirow{2}{*}{$\begin{array}{l}\text { To ask each other } \\
\text { 'why do you think } \\
\text { that?' so ideas are }\end{array}$} & \multirow{2}{*}{$\begin{array}{l}\text { To co- } \\
\text { operate with } \\
\text { classmates }\end{array}$} \\
\hline 19 & ID14 & Geog & 4 & 1 & 10 & 2 & 12 & 6 & 0 & $\checkmark$ & $\checkmark$ & $\checkmark$ & & $\checkmark$ & $\checkmark$ & & & \\
\hline
\end{tabular}




\begin{tabular}{|c|c|c|c|c|c|c|c|c|c|c|c|c|}
\hline 20 & ID14 & Geog & 6 & 0 & 6 & 2 & 3 & 3 & 0 & $\checkmark$ & $\checkmark$ & $\begin{array}{l}\text { backed up with } \\
\text { reasons }\end{array}$ \\
\hline
\end{tabular}


Appendix 5: Defining coordination in the dialogue coding scheme

\begin{tabular}{|l|l|l|}
\hline $\begin{array}{l}\text { Coord } \\
\text { (C) }\end{array}$ & $\begin{array}{l}\text { Synthesises or summarises collective } \\
\text { ideas (at least two, including own and/or } \\
\text { others' ideas). }\end{array}$ & $\begin{array}{l}\text { E.g. Emily showed good } \\
\text { understanding of the } \\
\text { historians, but David } \\
\text { cross-referenced their } \\
\text { positions better than she } \\
\text { did. }\end{array}$ \\
$\begin{array}{l}\text { Compares or evaluates different } \\
\text { opinions, perspectives and beliefs. }\end{array}$ & $\begin{array}{l}\text { I think we're in } \\
\text { agreement that a } \\
\text { suspension bridge would } \\
\text { be the best solution. } \\
\text { Proposes a resolution or consensus } \\
\text { view after discussion. }\end{array}$ \\
$\begin{array}{l}\text { Includes the invitational format of the } \\
\text { above. }\end{array}$ & $\begin{array}{l}\text { I see what you mean, I } \\
\text { agree with you now that } \\
\text { C is probably right, not B. }\end{array}$ \\
& $\begin{array}{l}\text { at least one of the co-ordinated inateas } \\
\text { should be quoted or paraphrased. }\end{array}$ & \\
&
\end{tabular}

